Article

\title{
Conservation and Use of Genetic Resources of Underutilized Crops in the Americas-A Continental Analysis
}

Gea Galluzzi $^{1, *}$ and Isabel López Noriega ${ }^{2}$

1 Bioversity International, Regional Office for the Americas, c/o CIAT, km 17 Recta Cali-Palmira, Cali, Colombia; E-Mail: g.galluzzi@gmail.com

2 Bioversity International, Via dei Tre Denari, 472/a Maccarese, Rome 00057, Italy; E-Mail: i.lopez@cgiar.org

* Author to whom correspondence should be addressed; E-Mail: geagalluzzi@gmail.com; Tel.: +57-2-445-0048 (ext. 108); Fax: +57-2-445-0096.

Received: 2 December 2013; in revised form: 7 February 2014 / Accepted: 7 February 2014 / Published: 21 February 2014

\begin{abstract}
Latin America is home to dramatically diverse agroecological regions which harbor a high concentration of underutilized plant species, whose genetic resources hold the potential to address challenges such as sustainable agricultural development, food security and sovereignty, and climate change. This paper examines the status of an expert-informed list of underutilized crops in Latin America and analyses how the most common features of underuse apply to these. The analysis pays special attention to if and how existing international policy and legal frameworks on biodiversity and plant genetic resources effectively support or not the conservation and sustainable use of underutilized crops. Results show that not all minor crops are affected by the same degree of neglect, and that the aspects under which any crop is underutilized vary greatly, calling for specific analyses and interventions. We also show that current international policy and legal instruments have so far provided limited stimulus and funding for the conservation and sustainable use of the genetic resources of these crops. Finally, the paper proposes an analytical framework for identifying and evaluating a crop's underutilization, in order to define the most appropriate type and levels of intervention (international, national, local) for improving its status.
\end{abstract}

Keywords: underutilized crops; NUS; genetic resources; Latin America; conservation and sustainable use; international policies 


\section{Introduction}

In an increasingly globalized and interdependent world, eradicating hunger and poverty is not only an ethical imperative but an essential prerequisite for peace and world security. The challenge of feeding the expected 9 billion world population by 2050 in a sustainable manner can be met, among other measures, by rescuing and using more diversity in agricultural and food production systems, both in terms of crop as in terms of varieties within any given crop [1,2]. The human population today derives most of its calories from a very narrow set of crops, with only about 30 species providing $95 \%$ of the global food energy [3,4]. On the contrary, over 7,000 species are known as edible and are either partly or fully domesticated, suggesting that a large share of potential food sources is underutilized $[5,6]$.

Latin America is home to a number of dramatically diverse agroecological regions which harbor a high concentration of crop diversity. This is particularly the case for the broadly defined diversity hotspots of Mesoamerica, the Andean region and the Amazon Basin, identified by Vavilov as key centers of plant domestication [7,8] and where genetic resources in traditional farming systems initially developed by indigenous people have undergone centuries of cultural and biological evolution. Some of the crops from those centers of origin and diversification have acquired global relevance (e.g., maize, potatoes, cassava), whereas others have retained a more local distribution. Early marginalization of some native crops may be traced back to the time of European colonization of Latin America; local species which were part of Pre-Columbian food systems were gradually substituted by crops from the Old World or local crops which attracted newcomers' attention [9]. More recent agricultural developments, particularly since the Green Revolution, deepened this marginalization by focusing on a package of staples (mostly wheat, maize and rice) on which a large percentage of the world population was already dependent for food security and to which priority investments were dedicated [10]. For these and other reasons, a number of Latin American edible plant species are nowadays considered minor, underutilized or neglected and, have joined a category of useful plant species often referred to as "NUS" (neglected and underutilized species). We will use the acronym as well as the adjectives listed above interchangeably throughout the study to refer to these crops.

Although a standard definition of NUS does not exist, a number of studies have described the typical features of NUS and the overriding issues affecting the conservation and use of their genetic resources [11-15]. In this paper, we aim to contribute to the discussion by critically analyzing the status of an expert-informed list of underutilized food crops in Latin America in light of the most commonly described features of underutilized crops. We also discuss the extent to which existing international policy and legal frameworks dealing with wild and cultivated biological diversity effectively support or not the conservation and sustainable use of underutilized crops' genetic resources.

\section{Methods}

In order to obtain an expert-informed list of crops which could be considered underutilized in Latin America, we prepared and circulated a survey to 120 experts involved in the conservation and use of plant genetic resources for food and agriculture (PGRFA) in 15 Latin American countries. In the survey, we asked them to list crops they considered underutilized in their country and to define their potential relevance, the limiting factors affecting their conservation in ex situ facilities, in the wild and on farm, and the effect of international biodiversity conventions on their conservation and sustainable 
use (text of the survey is available in Annex 1). The list of crops emerging from the survey was used to test the features commonly attributed to an underutilized crop and to analyze the influence of selected international policy frameworks on the conservation and use of their genetic resources. The selection of the common features was guided by Padulosi et al. 2004 [15]: the authors identified a series of characteristics which are attributed to NUS and their work is often cited as a reference in this subject area. Table 1 shows the criteria and the relative sources of information, in addition to the surveyees anweres, we used to evaluate the status of the crops in relation to each of the commonly attributed features considered.

Table 1. Criteria and relative sources of information for the evaluation of crops' status.

\begin{tabular}{ll}
$\begin{array}{l}\text { Feature Commonly Attributed } \\
\text { to Underutilized Crops }\end{array}$ & $\begin{array}{l}\text { Criteria and Sources of Information for Testing the Feature against the } \\
\text { Listed Crops }\end{array}$ \\
\hline
\end{tabular}

Limited research efforts devoted to the species

Number of hits in Google Scholar [16], using the common name and the scientific name of each of the species ${ }^{1}$. Google Scholar searches publications in scholarly literature of all disciplines.

Number of accessions of the species in Genesys (the database of the collections

Limited representation of the species in globally available $e x$ situ collections held by the consortium of international agricultural research centers of the CGIAR, the Department of Agriculture of the United States of America, USDA and public research institutes of the European countries) [17], in the catalogue of CATIE (Centro Agronómico Tropical de Investigación y Enseñanza) [18] and the database of the genebank at the World Vegetable Center (AVDRC) [19].

Number of accessions maintained in selected national genebanks (Bolivia,

Limited representation of the species in national ex situ collections Brazil, Ecuador, Mexico, Peru) ${ }^{2}$ according to the information provided by the World Information and Early Warning System (WIEWS) [20] of the Food and Agriculture Organization of the United Nations (FAO) and the countries' reports [21] for the preparation of the Second State of the World's Plant Genetic Resources for Food and Agriculture [22].

Limited efforts in germplasm Availability of internationally developed descriptors, according to Bioversity characterization International's list [23]

Number of hits in the Global Biodiversity Information Facility (GBIF) [24] which contains species' occurrence data associated to samples deposited in a

Limited knowledge of the species' distribution and number of national and international institutions working with plants (genebanks, herbaria, botanical gardens, etc.). ${ }^{3}$

production levels

Presence/absence of each crop in FAOSTAT [25], the database maintained by the Statistics Division of FAO, which provides data relating to food and agriculture production for 200 countries.

\footnotetext{
${ }^{1}$ We used English, Spanish and Portuguese common names for each of the species. The search was limited to the title of the publications included in Google Scholar from 1970 to 2013. Patents and citations were excluded.

${ }^{2}$ These countries were selected because of the predominance of answers we received from experts working there, and as an attempt to cover albeit partially some of the main hotspots of the continent's diversity.

${ }^{3}$ The search was restricted to Latin America and the Caribbean. Duplicates were removed and only georeferenced observations were retained, given that these are the only ones capable of providing direct, meaningful information on a species' distribution.
} 
Table 1. Cont.

\begin{tabular}{ll}
\hline $\begin{array}{l}\text { Feature Commonly Attributed } \\
\text { to Underutilized Crops }\end{array}$ & $\begin{array}{l}\text { Criteria and Sources of Information for Testing the Feature against the } \\
\text { Listed Crops }\end{array}$ \\
\hline $\begin{array}{l}\text { Number of long-term research and improvement programmes in selected } \\
\text { countries (Bolivia, Brazil, Ecuador, Mexico, Peru) from the countries' } \\
\text { reports for the preparation of the Second State of the World's Plant Genetic } \\
\text { Lesources for Food and Agriculture. }\end{array}$ \\
$\begin{array}{l}\text { Lack of plant breeding efforts } \\
\text { crop species }\end{array}$ & $\begin{array}{l}\text { Number of varieties in the Plant Variety Database (PLUTO) [26] of the } \\
\text { Union for Protection of Plant Varieties (UPOV), which includes varieties } \\
\text { registered in the national listings of varieties admitted for commercialization, } \\
\text { varieties subject to plant breeders' rights and varieties subject to plant sui } \\
\text { generis patents. }\end{array}$ \\
\hline
\end{tabular}

Table 2 shows the sources of information that we used to assess the impact of three selected international policy instruments on the conservation and use of the genetic resources of minor crops.

Table 2. Sources of information for the assessment of the influence of international policy instruments on the conservation and use of the genetic resources of minor crops.

\begin{tabular}{|c|c|}
\hline Inter & Source of the Information and Methodology for Analysis \\
\hline $\begin{array}{l}\text { Convention on Biological } \\
\text { Diversity }\end{array}$ & $\begin{array}{l}\text { In the project data base of the Global Environmental Facility (GEF) [27] we } \\
\text { performed a search of national and global projects dealing with agricultural } \\
\text { biodiversity between } 1991 \text { and 2012, measured against the total funds disbursed in } \\
\text { the biodiversity focal area. }\end{array}$ \\
\hline $\begin{array}{l}\text { International Treaty on } \\
\text { Plant Genetic Resources for } \\
\text { Food and Agriculture }\end{array}$ & $\begin{array}{l}\text { We used the information on the Benefit Sharing Fund's webpage [28] to identify } \\
\text { projects that deal with minor crops listed by the experts consulted in the survey. } \\
\text { The share of efforts devoted to underutilized crops by the Global Crop Diversity } \\
\text { Trust (GCDT) was measured by checking the list of the technical support } \\
\text { projects to ex situ collections which have been carried out [29]. }\end{array}$ \\
\hline $\begin{array}{l}\text { Global Plan of Action for the } \\
\text { Conservation and } \\
\text { Sustainable Utilization of } \\
\text { Plant Genetic Resources for } \\
\text { Food and Agriculture (GPA) }\end{array}$ & $\begin{array}{l}\text { We filtered information about NUS projects from the GPA project database [30] } \\
\text { and the national reports submitted to FAO for the preparation of the Second Report } \\
\text { on the State of the World's Plant Genetic Resources for Food and Agriculture. } \\
\text { This analysis focused on Bolivia, Brazil, Ecuador, Mexico and Peru }{ }^{1} \text {. The } \\
\text { information obtained from these sources was complemented with data available } \\
\text { on the websites of the largest public research organizations of these countries. }\end{array}$ \\
\hline
\end{tabular}

\section{Results}

\subsection{An Expert-Informed List of Underutilized Crops in Latin America}

We received 40 complete answers from researchers in 12 countries, resulting in a response rate of 30 per cent. Table 3 shows the respondents' field of expertise.

Although the response rate was relatively low, the number of crops listed as underutilized totalled 84 between genera and species (listed in Annex 2, Table A1). Species were more frequently reported, as requested in the survey, but in a few cases entire genera considered predominantly underutilized were also referred to (such as Cucurbita, Carica, Xanthosoma and Passiflora). We removed the three 
medicinal species which were reported, since the focus of the present article is on food crops. It is worth noting that $70 \%$ of the crops in our list are included in the list of Crops for the Future [31], an international organization with the mandate to document and promote research and awareness on underutilized species globally.

Table 3. Respondents' field of expertise. The total exceeds $100 \%$ because some respondents are involved in more than one field.

\begin{tabular}{lc}
\hline Respondents Field of Expertise & Percentages of Answers \\
\hline Ex situ conservation & 81.82 \\
In situ conservation & 27.27 \\
Crop improvement & 50 \\
Policies & 18.18 \\
Other & 34.09 \\
\hline
\end{tabular}

Acknowledging this list in no way represents a neither exhaustive nor definitive picture, we considered it as an informative guide to orient our analyses and discussions. As shown in Figure 1, fruits were by far the category hosting the largest share of underutilized crops with 38 highlighted species, followed by roots and tubers with 15 . All of the 38 fruit species are native to the continent, as well as all the 15 roots and tubers. Most of the species from other categories are also natives (88 per cent of the total), originating either in the Andean (e.g., grains and tubers), Mesoamerican (e.g., beans, sapotes) or Amazonian centers of diversity (cassava, peach palm, copuazú, among others).

Figure 1. Crop categories represented in the list of underutilized species resulting from the survey among Latin American experts.

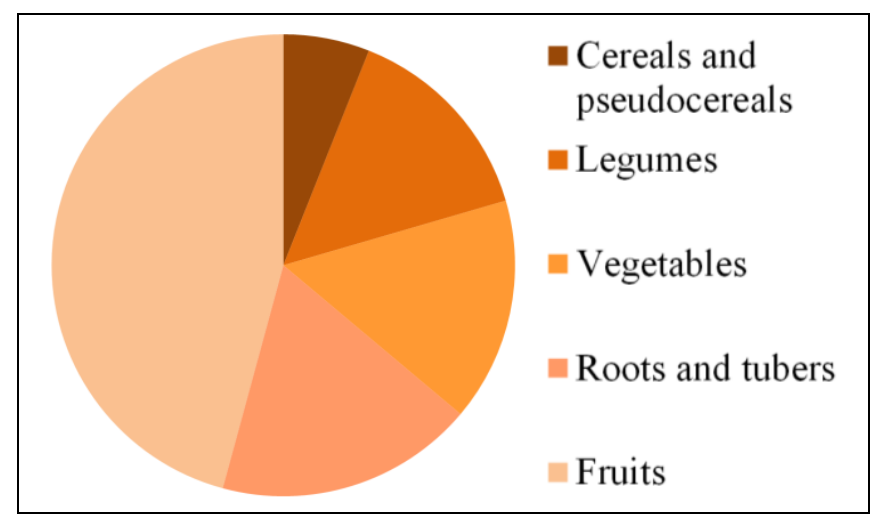

When asked to describe the potential use and relevance of each listed species, respondents almost invariably (in $95 \%$ of the cases) selected more than one option, suggesting that underutilized crops have a multi-purpose potential. Nevertheless, the most frequent answer was dietary diversification, equaled by diversification of agricultural systems and followed by food security.

\subsection{Testing NUS Features against the List of Latin American Underutilized Crops}

This section presents the results of our testing of the common features attributed to neglected and underutilized crops against the list of species obtained from the survey, combined with the 
respondents' perceptions. Some of the tested features have to do with research and conservation (Sections 3.2.1 and 3.2.2) whereas others are more related to use (Sections 3.2.3 and 3.2.4).

\subsubsection{Limited Research Efforts Dedicated to the Species}

Our survey revealed that the lack of research efforts only came third in the ranking of the main limiting factors affecting conservation and use of minor crops' genetic resources. When complementing this perception with an analysis of the degree of widely available scientific literature using Google Scholar searches performed in November 2013, we found that the average number of hits for our species was 1,954. Out of the 84 crops constituting our list, 67 species (i.e., 79 per cent) have a lower than average number of hits, whereas the remaining 17 are above average. For an idea of scale, the score in literature hits for major cereals (rice, wheat and maize) with the same search criteria was just below 99,000, while for major vegetables (average between cabbage and tomato) it was 42,000. For chili pepper, common bean and potato (considered the major spice, legume and root/tuber of reference) we retrieved respectively 63,300,31,600 and 67,400 hits. Average number of hits for three major fruit crops (pineapple, papaya and apple) was 25,540. All these values, as expected, largely exceed the average of hits retrieved for the crops treated here (Table 4).

Table 4. Comparison between literature hits in Google Scholar between the crops in the Latin American list of underutilized species and selected reference major crops.

\begin{tabular}{lclcl}
\hline \multicolumn{1}{c}{ NUS Categories } & Average N. Hits & & Average N. Hits & Major Crop of Reference \\
\hline Cereals, pseudocereals & 3,494 & $\longleftrightarrow$ & 98,967 & Maize, wheat, rice \\
Fruits & 1,056 & & 25,540 & Apple, pineapple, pawpaw \\
Legumes & 2,013 & & 31,600 & Common bean \\
Roots and tubers & 2,697 & & 67,400 & Potato \\
Vegetables & 1,768 & & 31,345 & Cabbage, tomato \\
\hline
\end{tabular}

Species which feature in Google Scholar with a number of hits below the dataset's average (i.e., less than 1,954 hits) are mostly crops natives to the continent (with only four exceptions, being exotic vegetables like verdolaga, winter melon, sponge gourd and lablab bean). Species at the top end of the range, with over 5,000 literature hits, are mostly crops of broad worldwide cultivation and commercial distribution (asparagus, sweet potato, cowpea, chilies and cassava).

\subsubsection{Limited Representation in ex situ Collections}

\subsubsection{International Collections with Facilitated Access}

It is often argued that a common feature of NUS is that they are conserved mostly on-farm and scarcely represented in ex situ collections [15], particularly in those collections which make their samples and the related documentation freely available for research and development purposes. Most PGRFA-based agricultural research in developing countries has been possible thanks to the germplasm conservation, documentation, characterisation and distribution services of the network of genebanks of the CGIAR [32]. Other institutions with vast, well documented and freely available collections which have been and still are instrumental in providing the genetic basis for breeding and improvement 
programs of a number of crops are the European genebanks, and those of the USDA-ARS (Agricultural Research Service of the US Department of Agriculture), CATIE (Centro Agronómico Tropical de Investigación y Enseñanza) and AVRDC (The World Vegetable Center).

Of all the crops in the list, 17 (i.e., 20\%) have no accession in these genebanks and another 26 have less than 10 accessions, confirming that many of the species reported to be neglected are indeed poorly represented in international and regional collections. On the other hand, 22 of the crops listed as underutilized in the survey have between 100 and 5,000 accessions, countering the above mentioned negative picture. Crops which are absent or poorly represented are mostly fruit species (together with a root and two vegetables, all native); this is partly explained by the fact that most of the checked genebanks' mandate focuses on annual crops and partly by the difficultly and high cost of storing and maintaining perennials in field collections or in vitro. Even in the case of CATIE, with its extensive field collection in Costa Rica, fruit trees still occupy the lower end of the range in terms of numbers of accessions, with the notable exception of peach palm (Bactris gasipaes with over 600 samples). At the opposite end of the range of representation in the surveyed genebanks are crops such as sweet potato, cassava, cowpea, pigeon pea and squashes, which are the only ones in our list with collections exceeding 5,000 accessions.

\subsubsection{National ex situ Collections}

In our survey, regional experts from Latin America did not rank ex situ conservation high among the critical areas of neglect for the species they listed. Our analyses show that, for many underutilized species in selected countries, there is a good level of representation in national genebanks (Annex 3). Collections of national agricultural research organizations in Bolivia, Ecuador and Peru (Table A2 of Annex 3) contain on average 38 of the underutilized species reported in the survey with an average 270 accessions each. Brazilian collections (Table A3 of Annex 3) store a wealth of tropical fruit trees and horticultural plants native to the continent, containing 27 of the species reported here (represented by an average 647 accessions); in Central America, the Mexican network of germplasm collections includes 53 of the crops reported in the survey, with average accession number of 365 (Table A4 of Annex 3).

However, when measuring the size of each species' collection against the average size of all underutilized crops' collections in each country, it appears that most underutilized species in national genebanks are conserved by a lower than average number of accessions (Figure 2), with a few champions contributing to the relatively high average number recorded. Underutilized species whose collections are well above average in the Andean region are mostly native grains and tubers. Quinoa collections reach 4,000 and 1,980 accessions in Bolivian and Peruvian collections, together with 487 and 2,217 accessions of oca (Oxalis tuberosa); over 2,000 accessions of South American lupin are conserved in Peru; native potatoes (a different set of species than the common potato) are represented by 1,760 accessions in Bolivia. In Brazil, the species whose collections greatly exceed average are legumes (Phaseolus lunatus with 2,673 accessions, Vigna with 1,787 accessions) and squashes (5,675 entries) and the large Passifloraceas fruit family. Only three crops in the Mexican genebanks have collections with more than average accessions, namely those of amaranth, chilli peppers and squashes.

A commonly observed trend in all countries is the tendency of most fruits species to occupy the lowest end of the collection size ranges, for likely the same reasons described for international collections. 
Figure 2. Percentage of underutilized species conserved in national gene banks whose collections are represented by a lower than average number of accessions (light green), and percentage of those which are above average (dark green).

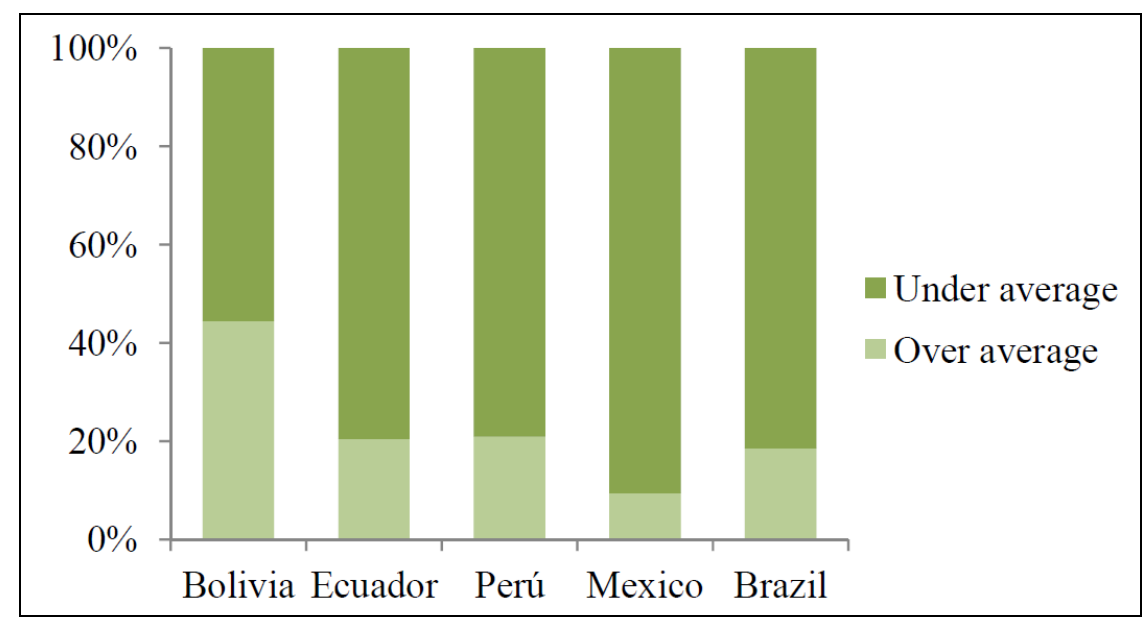

However, number of accessions per se is not a sufficient indicator of a species' status of ex situ conservation. Quality of the material in terms of viability and availability of accurate passport and/or characterization and evaluation data is an additional, essential measure of a collection's conservation status, since availability of this data is a precondition for using the genetic material in breeding or research. Survey respondents pointed to the technical and financial limitations to maintaining collections in good shape. Crop descriptors, which provide unambiguous guidelines for the documentation of accessions, have been developed at international level and made publicly available for only 22 of the 87 crops listed here. For one (a palm species from southern Brazil, Butia odorata) descriptors are currently under preparation thanks to a collaboration between Bioversity International and Brazilian experts. This of course does not exclude the likelihood of scientists using locally developed descriptors in their daily work, but this approach may limit broader sharing and comparison of their results.

\subsubsection{Limited Knowledge on the Species' Distribution and Production}

The lack of efforts in on-farm conservation was considered to be the most serious limiting factor to the enhancement of minor crops and, in turn, their use within farming systems by 75 per cent of the surveyed experts in the Americas. An important step towards improving the on-farm conservation of any species is having data about its current (and potential) distribution and cultivation. In addition to individuals' knowledge on these aspects, publicly available georeferenced data is a powerful starting point for studies on a crop's agroecological potential and adaptive capacity which in turn are useful for planning in situ conservation initiatives [33-35]. Searches performed in the data portal of the GBIF resulted in retrieval of georeferenced data for almost all the species. There is great variation in the number of observations across our dataset, ranging from no points (for only three species, all fruits) to over 2,000 for bean species (Phaseolus lunatus and Phaseolus coccineus), sweet potato and chili peppers (the latter considered as whole genus); cassava still totaled almost 5,000 observation points. Observation points for each species were spread across an average of nine countries within Latin America. Half of the species are represented by a lower than average number of observations, most often less than 500 (Figure 3). It is interesting to observe that half of the species with less than 50 observations are fruits and roots and tubers. 
Figure 3. Number of observations recorded in GBIF for the species listed in our survey. Most species are recorded with less than 500 georeferenced observation points.

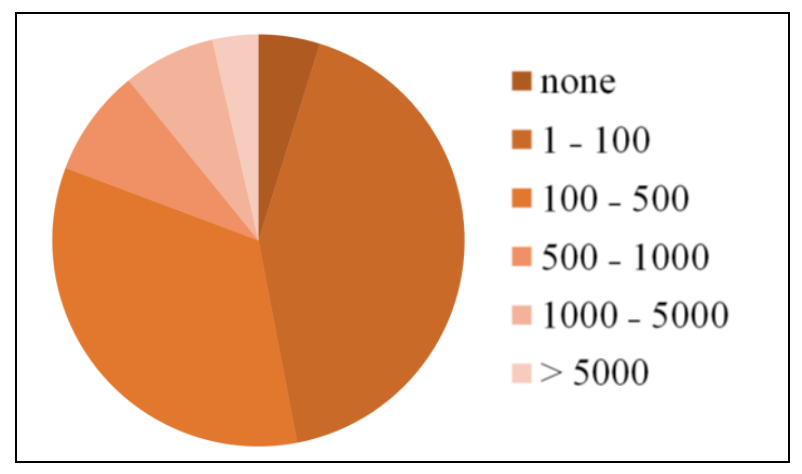

In terms of publicly available information on the production levels of our crops, the FAOSTAT database, which gathers and elaborates national statistics from FAO member countries, covers only 11 of our underutilized species, plus 7 generic categories which are likely to include them (such as "tropical fruits" and "roots and tubers"), over the 156 crop or crop categories represented. FAOSTAT's section on methods and standards acknowledges that generally, production data relates to plantation crops or orchard crops grown mainly for sale, excluding many minor crops which are conserved for self-consumption or sale through local, informal channels. In particular, it is flagged that statistics on some species, particularly tropical fruits, are unavailable in many countries, and where reported often lack uniformity. We were able to access public agricultural statistics data only for Brazil [36], Mexico [37] and Peru [38]. While Brazilian statistics only mentioned major crops already covered in FAOSTAT, the Mexican and Peruvian databases allowed consulting information on some of the underutilized crops listed by our respondents (but only an additional seven in each country).

\subsubsection{Lack of Plant Breeding Efforts and Commercial Varieties}

A varying number of underutilized crops among those highlighted in the survey are object of institutional, longer term research and improvement programmes (see Tables 5 and 6).

These lists are likely not to be complete, but highlight significant attention to minor crops in Andean countries and to a certain extent in Mexico and Brazil (this may also depend on the smaller number of answers received from these countries and thus the smaller representation of their NUS in our list). It is important to recall that species which have been somewhat neglected by breeding are likely to harbor significant levels of genetic diversity, which not only makes them of great conservation value may also be allowing their continued adaptation to marginal environments and small-scale, low-input farming systems [39]. Therefore, breeding approaches which strive for maintaining a broad genetic basis while achieving the needed improvements in agronomic performance, product uniformity or other important aspects may be particularly relevant. The approaches commonly used in participatory plant breeding frequently aim at striking such a balance and encouraging the maintenance of diversity [40]. Curiously, in participatory breeding (PPB) programs in the Americas, underutilized crops are rarely represented: we are aware only of experiences of participatory variety selection only in the Andes on native potatoes [41,42] and of an interest and willingness to expand the maize and bean-based activities carried out in a number of Central American countries under the umbrella of the Mesoamerican Programme on Participatory Breeding to minor crops [43,44]. 
Table 5. Underutilized crops for which a public breeding or evaluation program exists in selected Andean countries.

\begin{tabular}{|c|c|c|c|c|}
\hline \multirow{2}{*}{\multicolumn{2}{|c|}{ Crop }} & \multicolumn{3}{|c|}{ Country } \\
\hline & & Peru & Ecuador & Bolivia \\
\hline Amaranth & Amaranthus caudatus & $\checkmark$ & $\checkmark$ & \\
\hline Chirimoya & Annona cherimola & $\checkmark$ & $\checkmark$ & \\
\hline Soursop & Annona muricata & & $\checkmark$ & \\
\hline Borojó & Borojoa patinoi & & $\checkmark$ & \\
\hline Pigeon pea & Cajanus cajan & $\checkmark$ & & \\
\hline Chili pepper & Capsicum spp. & $\checkmark$ & & \\
\hline Papayas & Carica/Vasconcellea spp. & $\checkmark$ & $\checkmark$ & \\
\hline Cañihua & Chenopodium pallidicaule & $\checkmark$ & & $\checkmark$ \\
\hline Quinoa & Chenopodium quinoa & $\checkmark$ & $\checkmark$ & $\checkmark$ \\
\hline Squashes & Cucurbita spp. & $\checkmark$ & & \\
\hline Tree tomato & Cyphomandra betacea & & $\checkmark$ & \\
\hline Arazá & Eugenia stipitata & $\checkmark$ & $\checkmark$ & \\
\hline Sweet potato & Ipomoea batatas & $\checkmark$ & & \\
\hline Andean lupin & Lupinus mutabilis & & $\checkmark$ & \\
\hline Cassava & Manihot esculenta & $\checkmark$ & & \\
\hline Camu camu & Myrciaria dubia & $\checkmark$ & & \\
\hline Maracuyá & Passiflora edulis & $\checkmark$ & $\checkmark$ & \\
\hline Granadilla & Passiflora ligularis & $\checkmark$ & & \\
\hline Avocado & Persea americana & $\checkmark$ & $\checkmark$ & \\
\hline Lima bean & Phaseolus lunatus & $\checkmark$ & & \\
\hline Inca berry & Physalis peruviana & $\checkmark$ & $\checkmark$ & \\
\hline Lúcuma & Pouteria lucuma & $\checkmark$ & & \\
\hline Guava & Psidium guajava & & $\checkmark$ & \\
\hline Sapote & Puteria sapota & $\checkmark$ & $\checkmark$ & \\
\hline Andean berries & Rubus spp. & & $\checkmark$ & \\
\hline Lulo & Solanum quitoense & & $\checkmark$ & \\
\hline Native potatoes & Solanum tuberosum ssp. andigenum & $\checkmark$ & $\checkmark$ & $\checkmark$ \\
\hline Pitaya & Stenocereus spp. & $\checkmark$ & $\checkmark$ & \\
\hline Copuazú & Theobroma grandiflorum & & $\checkmark$ & \\
\hline Cowpea & Vigna unguiculata & $\checkmark$ & $\checkmark$ & \\
\hline
\end{tabular}

Commercialization of seed of varieties resulting from breeding efforts is often preceded by a series of procedures aimed at officially evaluating and releasing the plant variety in the country where its commercialization is sought. Officially released plant varieties are commonly listed in national registers of commercial varieties. The presence of minor species in such registers can therefore be taken as an indication of, first, public and private organizations' breeding work on such species and, second, their interest in the commercialization of seed of improved varieties of the species, which suggests, in turn, that there is a demand for such species among farmers. The same can be said about species included in the national and international catalogues of varieties subject to plant breeders' rights. The Union for the Protection of Plant Varieties maintains a database of plant varieties included in the registers of commercial varieties and in the catalogues of varieties protected by plant breeders' 
rights or plant patents in UPOV member countries. According to the information in this database, out of the 84 crops in our list, 37 have at least one variety registered in national listings or protected by plant breeder's rights or plant patents, representing around $43 \%$ of the total. The number of registered varieties however is highly variable, ranging from one as in the case of Andean fruit Physalis peruviana to over 500 as for asparagus. The species with no registered varieties under UPOV's database are in the great majority fruits and roots and tubers. Only 13 of the fruits species out of 38 reported by experts have commercially registered varieties, the average being five varieties; of the 15 roots and tubers searched in UPOV's database, only five have commercial varieties, the average being nine (including cassava which alone has over 17 varieties). For comparison, major staples such as wheat and maize, have 39,000 and 89,000 registered commercial varieties, whereas major fruit species such as apple and avocado have over 3,000 and over 100 respectively.

Table 6. Underutilized crops for which a public breeding or evaluation program exists in Brazil (left) and Mexico (right).

\begin{tabular}{ll|ll}
\hline & Brazil & \multicolumn{2}{c}{ Mexico } \\
\hline & Crop & \multicolumn{1}{c}{ Crop } \\
\hline Copuazu & Theobroma grandiflorum & Chili peppers & Capsicum spp. \\
Cassava & Manihot esculenta & Amaranth & Amaranthus caudatus \\
Agraz & Vaccinium spp. & Squashes & Cucurbita spp. \\
Peach palm & Bactris gasipaes & Papayas & Carica/Vasconcellea spp. \\
Chili pepper & Capsicum spp. & Prickly pear & Opuntia ficus-indica \\
Squashes & Cucurbita spp. & Avocado & Persea americana \\
Quinoa & Chenopodium quinoa & Chirimoya & Annona cherimola \\
Passifloras & Passiflora spp. & Chayote & Sechium edule \\
Surinam Cherry & Eugenia uniflora & Pitaya & Stenocereus spp. \\
Feijoa & Acca sellowiana & Chili pepper & Capsicum spp. \\
Jelly Palm & Butia capitata & Amaranth & Amaranthus caudatus \\
Rio Grande Cherry & Eugenia involucrata & Squashes & Cucurbita spp. \\
\hline
\end{tabular}

\subsection{The Influence of International Biodiversity Conventions and Programs on the Conservation and} Use of Genetic Resources of Underutilized Crops in the Americas

In the last decade, the attention paid to minor crops by international policy making has increased considerably. As international conventions, programs, initiatives and projects dealing with the conservation and use of wild and domesticated biodiversity and food security have proliferated, the interest in underutilized species as key examples of the genetic diversity under threat and as potential contributors to food security has grown. However, to what extent do these international instruments have an influence on countries' management of NUS' genetic resources? Have they been able to effectively improve their conservation and sustainable use? In this section, based on data from Latin America, we critically analyze the commitments related to minor crops assumed by parties to two international conventions and one international plan of action that represent the most relevant international instruments in the area of plant diversity conservation and sustainable use. 


\subsubsection{The Convention on Biological Diversity}

The Convention on Biological Diversity (CBD) was the first international instrument to address conservation, sustainable use and equitable sharing of benefits derived from the utilization of all biological diversity. All Latin American countries are members of the CBD. Since its entry into force in 1993, the parties to the CBD have agreed on an innumerable amount of strategies and programmes that translate the general obligations stated in the convention's text into concrete measures to be adopted at the local, national and regional levels. Some of these are more relevant than others for the conservation and use of domesticated species. In 2002, the member countries of the CBD agreed to put in place a Global Strategy for Plant Conservation (Annex to decision VI/9) with the ultimate goal to halt the continuing loss of plant diversity. It includes 16 outcome targets to be met by 2010 , target 9 being the most relevant for cultivated species: "70 per cent of the genetic diversity of crops and other socioeconomically valuable is plant species conserved, and associated indigenous and local knowledge maintained". The CBD's program on agricultural biodiversity (established with Decision VI/5 of the Conference of the Parties in 2000) includes an initiative on biodiversity for food and nutrition which explicitly calls for "identification and promotion of species currently underutilized or of potential value to human food and nutrition, including those important in times of crisis, and their conservation and sustainable use" [45].

Around 20 per cent of the respondents to the survey acknowledged that increased attention had been devoted to in situ conservation of biological diversity, after the entry into force of the CBD in 1993. However, 60 per cent of respondents pointed that due to the convention's focus on wild biodiversity conservation and the fact that its implementation resides in the hands of Ministries of the Environment, the consideration of crop and agricultural issues is relatively weak within this framework. Interventions in the field of agricultural genetic resources directly supported by the CBD's financial mechanism are much less far-reaching than those in the field of wild biodiversity conservation. The Global Environment Facility (GEF) has been functioning since 1996 as the institutional structure to operate the financial mechanism of the Convention, providing countries and institutions with funds for carrying out conservation and sustainable use initiatives. From 1992 to 2012, agricultural biodiversity projects in the Americas received only $1.8 \%$ of the overall GEF funds disbursed at national level in the biodiversity focal area, spread out over seven projects out of 211 . These seven projects (in Argentina, Bolivia, Chile, Colombia, Cuba, Ecuador and Peru) include at least some minor crops among their target portfolio, the greatest emphasis being observed in the Andean region with a focus on grains, roots and tubers and a few fruit species. In terms of GEF funds for regional or global projects including a Latin American country, agricultural biodiversity projects received a greater share of funds, reaching 9.5 per cent of the total biodiversity budget, spread over four projects out of 43 of the biodiversity focal area. Three of these include at least a partial focus on underutilized species. Figure 4 shows the small share of agro-biodiversity projects within the overall funding of the GEF.

The CBD recognized countries' sovereign rights over the genetic resources within their territories, and introduces an obligation for users of such resources to share the benefits arising from their utilization with the countries where the resources were obtained. The international recognition of countries' fundamental rights and obligations in relation to the access to, and use of genetic resources (commonly referred to as access and benefit-sharing or ABS) was brought up to avoid appropriation of 
plant genetic resources from developing countries, by commercial actors usually operating in developed countries, with no benefit or involvement of the provider [46,47]. In 2010, the Conference of the Parties to the CBD adopted the Nagoya Protocol on Access to Genetic Resources and the Fair and Equitable Sharing of Benefits Arising from their Utilization, which elaborates the rights and obligations of the parties to the Convention in relation to ABS. The Nagoya Protocol has not entered into force yet. The complexity of the ABS procedures developed in many countries and the limited capacity to implement them at national level are often cited as major limitations to research on any country's biodiversity, including agricultural biodiversity and native crops [48-50]. The results of our survey point to the same direction: a strong point raised by 40 per cent of respondents when surveyed on the effect of the CBD on conservation and use of neglected crops' germplasm, resides in access and benefit sharing rules. This area of influence of the CBD was the only one in which a specific (negative) effect was detected in particular on minor species, conserved both in and ex situ. Perhaps the most loudly voiced concerns about access, emerging from our survey and confirmed in literature, have to do with the effects of the Andean Decision 391, directly or through derived legislation, on the Andean Community of Nations (Bolivia, Colombia, Ecuador, and Peru). Difficulties with the Brazilian and Mexican laws have also been reported [51]. Since the main scope of these legislations is in situ material [52], those genetic resources of minor crops which are mostly conserved on-farm rather than in genebanks fall under these usually complex and lengthy legal arrangements. Although some countries developed somewhat simplified procedures for access to material from genebanks (mostly through the design of institutional material transfer agreements, MTAs), the unclear legal scenario created around genetic resources is perceived to have affected the ease with which genebank curators grant access to their collections, for fear of infringing national law and the country's sovereign rights, particularly when the object are collections of their native crops. Data from Peru exemplify this uncertainty: the national genebank sent out genetic material under 35 MTAs for research purposes over the 2001-2009 time period but rejected applications which upfront mentioned a commercial development [53]. Respondents to the survey from other countries confirmed this tendency, in which fears of not complying with the national ABS legislation and thus exposing the nation's genetic heritage to misappropriation, combined with limited negotiation capacities of the competent authorities, make rejection a common reaction to a number of germplasm requests.

Figure 4. Share of Global Environmental Facility (GEF) funds (in million US dollars) and of GEF projects (numbers) dedicated to biodiversity and agricultural biodiversity within the overall funding strategy.

\begin{tabular}{|r}
\hline 900 \\
800 \\
700 \\
600 \\
500 \\
400 \\
300 \\
200 \\
100 \\
0
\end{tabular}




\subsubsection{The International Treaty on Plant Genetic Resources for Food and Agriculture}

The International Treaty (ITPGRFA) operates in harmony with the CBD, sharing the objectives of conservation, sustainable use and equitable benefit-sharing but with a narrower focus on plant genetic resources for food and agriculture, in recognition of their "special nature $[\ldots],[\ldots]$ distinctive characteristics and problems, which require specific solutions" (Decision II-15 of the International Undertaking on PGRFA, Jakarta 1995). After seven years of negotiations under the auspices of FAO, the ITPGRFA was adopted in 2001, and entered into force in 2004. At the time we write this article (November 2013), 16 out of the 26 countries in Latin America are parties to the ITPGRFA.

The ITPGRFA creates a multilateral system of access and benefit sharing in which parties provide facilitated access to plant genetic resources for research, breeding, conservation and training, and commit to contribute part of the monetary benefits which may arise from the use of such resources to a common fund managed by the Governing Body of the Treaty (the Benefit Sharing Fund). The genetic resources subject to the multilateral system of the Treaty are those of species listed in the Annex 1 of the Treaty (35 globally relevant crops and 29 forages [54]), which are under the management and control of the Treaty parties and in the public domain; hosted in international ex situ collections like the ones of the CGIAR centers and institutions like CATIE in Latin America (according to the Treaty's Article 15 which deals with the agreements established between the Treaty's Governing Body and International Agricultural Research Centers, with regard to their ex situ collections); and those voluntarily included by other national and international organizations or individuals, for example companies or private collectors. The ITPGRFA's multilateral system offers an alternative to bilateral ABS agreements inspired by the CBD, for an important subset of the world's biodiversity. The text of the Treaty explicitly mentions the importance of conserving "those PGR that are under threat or are of potential use" [54] (Article 5b) and promoting the use of "local and locally adapted crops, varieties and underutilized species" [54] (Article 6.2e). Through an entire section on farmers' rights [54] (Article 9), the Treaty also calls for protection of the rights of small scale farmers and for recognition of their traditional production systems, which provides additional space for initiatives enhancing conservation and use of minor crops and traditional varieties.

Almost all respondents to the survey (average 66 per cent) feel that the ITPGRFA has not determined significant changes in the status of conservation and use of underutilized crops; this perception of a lack of influence on minor species is particularly felt in terms of their on-farm conservation (80 per cent of respondents) versus ex situ conservation. The fewer respondents which did feel the ITPGRFA had a somewhat differentiated effect depending on the species, reported that germplasm distribution (30 per cent), breeding ( 29 per cent) and international funding (36 per cent) had improved only for major, globally distributed staples.

The correlation between countries' obligations under the ITPGRFA and their efforts to conserve and promote the sustainable utilization of minor crops in Latin American countries is not easy to measure. The number of projects targeting NUS which have been funded by the two financial mechanisms of the ITPGRFA may be used as a tentative measure of the Treaty's influence. One of these mechanisms is the Global Crop Diversity Trust (GCDT), which makes funds available for improving and upgrading the status of ex situ collections included in the multilateral system, and the second one is the benefit sharing fund, which supports actions covering all aspects of PGRFA management. Underutilized species in the Americas have only partially benefitted from the GCDT's 
funds. Over the three rounds of funding released to date (2008 to 2010) only few of the minor crops listed by our experts, namely Peruvian and Argentinian sweet potato collections and Mexican collections of common bean, lima bean and cowpea, have been targeted by evaluation projects. No collection project has been funded in Latin America in the 2010 round of funding. In terms of regeneration, funds from the Trust have allowed securing vulnerable accessions of 22 priority crops, including cassava, cowpea, taro, pigeon pea, sweet potato and yam among those listed here. The Trust has also launched a project in partnership with the Millennium Seed Bank of the Royal Botanic Gardens in Kew which will safeguard and use the wild relatives of 29 crops of major importance to food security, of which only four coincide with species in our list (cowpea, lima bean, pigeon pea, sweet potato). One of the explanations for this low coverage of crops from our list in the GCDT's portfolio is that its operational strategy, which is independent from the Treaty's Funding Strategy, explicitly prioritizes ex situ collections of species listed in the Annex 1 of the Treaty, i.e., major species of global importance and distribution. Furthermore, even if exceptions are made to this Annex 1 preference, the Trust funding mechanism also requires that the target collections be effectively exchanged according to the rules of the multilateral system of access and benefit-sharing, i.e., be placed within the MLS. These conditions are seen by some respondents as a limitation to the possibility of obtaining funds for the conservation of those underutilized crops which parties are not necessarily willing to put in the multilateral system and prefer keeping under the CBD-inspired access and benefit sharing mechanism in place. It is anyhow important to acknowledge that the Trust has also supported broader initiatives such as the drafting of the Hemispheric Strategy for the Americas [55], which aimed at assessing the most important crops and collections in the hemisphere and providing recommendations for their continued ex situ conservation. Forty-nine of the total 85 species in the Hemispheric Strategy's list overlap with those highlighted in the present survey.

The benefit sharing fund of the Treaty, whose priorities are informed by the Treaty's Funding Strategy (adopted by the Governing Body of the Treaty at its first session, Resolution 1/2006) and its Annexes on eligibility criteria and funding priorities (adopted by the Governing Body at its Second Session in 2007), does not have a formally declared intention to focus on specific crop categories. Admittedly, a requirement to focus on Annex 1 crops was introduced in one of the two windows which made up the second call for proposals (released in 2010), making roughly half of the funding portfolio unavailable to most NUS in that cycle. Overall, out of the nine projects awarded funding in Latin America, only two explicitly target underutilized crops from our list. Another three include underutilized species among the portfolio of target crops (see Table 7 for details).

The creation of the Treaty's multilateral system of access and benefit sharing has not until now addressed the shortcomings of CBD-inspired ABS rules in Latin America due to a great extent to the very modest level of implementation of the system in most of the ITPGRFA member countries [56]. The only Latin American country that has officially notified the national ex situ collections included in the multilateral system is Brazil with rice, maize, bean and cassava collections held by Embrapa. Except for Embrapa's cassava collection, no national collection of any minor crop among those listed here has been included in the multilateral system. However, even under the best-case scenario of a well implemented multilateral system, many underutilized crops are likely not to be covered by its scope: only $14(16 \%)$ of the species reported as underutilized here are in the Annex 1 of the ITPGRFA (although parties are free to place non-Annex 1 collections in the system), and most of the genetic 
resources of those species are found on-farm, for which the application of the rights and obligations of the Treaty's multilateral system is unclear. Only three of the 22 respondents who expressed and motivated their opinion on the possible benefits of the Treaty's implementation to conservation and use of NUS germplasm, mentioned they did not see any benefits; the other experts feel there is scope for ITPGRFA-driven improvements in minor crops' status.

Table 7. Projects supported by the Treaty's Benefit Sharing Fund in its current two rounds of funding and coverage of underutilized crops.

\begin{tabular}{|c|c|c|c|}
\hline & Title & $\begin{array}{l}\text { Targeted country or } \\
\text { countries }\end{array}$ & $\begin{array}{l}\text { Focus on } \\
\text { underutilized } \\
\text { crops }\end{array}$ \\
\hline \multirow{5}{*}{$\begin{array}{l}\text { First } \\
\text { round } \\
\text { projects }\end{array}$} & $\begin{array}{l}\text { Identification of useful potato germplasm adapted to biotic } \\
\text { and abiotic stresses caused by global climate change }\end{array}$ & Costa Rica & no \\
\hline & $\begin{array}{l}\text { Rescue, conservation and sustainable management of } \\
\text { teocintle in Nicaragua (Zea nicaraguensis Iltis \& Benz) } \\
\text { in the Apacunca Genetic Reserve }\end{array}$ & Nicaragua & no \\
\hline & $\begin{array}{l}\text { Contribution of traditional methods for the } \text { in situ } \\
\text { conservation and management of maize (Zea mays L.) } \\
\text { and bean (Phaseolus spp.) to the food security of } \\
\text { farming families in Cuba }\end{array}$ & Cuba & no \\
\hline & $\begin{array}{l}\text { Conservation and Sustainable Use of Native Potato } \\
\text { Diversity in the "Potato Park"; Cusco, Peru }\end{array}$ & Peru & yes \\
\hline & $\begin{array}{l}\text { Broadening of potato (Solanum tuberosum) genetic } \\
\text { basis through introgression of local wild species, } \\
\text { Solanum commersonii }\end{array}$ & Uruguay & no \\
\hline \multirow{4}{*}{$\begin{array}{l}\text { Second } \\
\text { round } \\
\text { projects }\end{array}$} & $\begin{array}{l}\text { Participatory and science-based formulation of a } \\
\text { Strategic Action Plan to strengthen the conservation of } \\
\text { plant genetic resources and their enhanced use in } \\
\text { adapting to climate change in Mesoamerica }\end{array}$ & $\begin{array}{l}\text { Guatemala, Belize, } \\
\text { El Salvador, Honduras, } \\
\text { Nicaragua, Costa Rica, } \\
\text { Panama, Mexico }\end{array}$ & partial \\
\hline & $\begin{array}{l}\text { Shared management and use of (agro)biodiversity by } \\
\text { indigenous and the traditional communities from the semi- } \\
\text { arid region of Minas Gerais State as a strategy for food } \\
\text { security and to reduce climate risks }\end{array}$ & $\begin{array}{l}\text { Brazil with partner } \\
\text { applicants in: Costa } \\
\text { Rica, Nicaragua, } \\
\text { Guatemala, Cuba, } \\
\text { Haiti, Mozambique }\end{array}$ & partial \\
\hline & $\begin{array}{l}\text { Conservación y manejo sostenible del germoplasma de } \\
\text { papas nativas en las comunidades campesinas de la } \\
\text { Provincia de Andahuaylas }\end{array}$ & Peru & yes \\
\hline & $\begin{array}{l}\text { Establecimiento de una red preliminar de bancos } \\
\text { comunitarios de semillas, en regiones vulnerables del país, } \\
\text { para disponer de semillas en caso de desastres naturales }\end{array}$ & Guatemala & partial \\
\hline
\end{tabular}

3.3.3. The Global Plan of Action for the Conservation and Sustainable Use of Plant Genetic Resources for Food and Agriculture

The Global Plan of Action for the Conservation and Sustainable Utilization of Plant Genetic Resources for Food and Agriculture (GPA) is a set of recommendations developed by the Commission 
on Genetic Resources for Food and Agriculture of FAO, and based on the Report on the State of the World's Plant Genetic Resources for Food and Agriculture. The GPA was adopted by 150 countries in 1996, and renewed in 2011, and is intended as a framework, guide and catalyst for action at community, national, regional and international levels. Unlike the CBD and the ITPGRFA, the GPA does not spell out member countries' rights and obligations but rather 20 priority activity areas grouped into four thematic sections: in situ conservation and development; ex situ conservation; utilization of plant genetic resources and institutions and capacity building. Although most activity areas of the plan are relevant for the conservation and sustainable use of minor and underutilized plant species, activity area 12 deals explicitly with minor species, encouraging actions to "identify underused species, develop sustainable management practices, develop post-harvest and marketing methods, and promote policies for the development and use of under-utilized species", based on their "potential for wider contributions to food security, agricultural diversification and income generation".

According to their reports to FAO under the GPA, Andean countries have directed $39 \%$ of their total ex situ projects to underutilized species as defined in the survey. Peru has the highest ratio, with $51 \%$ of projects being on minor crop collections (covering 28 of the species resulting from the survey). Bolivia has been giving high priority to quinoa, Ecuador to Andean fruit species such as cherimoya (Annona cherimola) and naranjilla (Solanum quitoense), while Peru has largely focused on Andean tubers [57-59], as exemplified in Figure 5. Respondents from the Andean region noted that although there had been some degree of national research and development efforts on NUS, they tended to focus on a narrow set of crops, especially those with increasing demand on national and international markets; this is the case of Andean grains, spearheaded by quinoa. Brazil's report to FAO (no information is available through the GPA portal) highlights significant investments in the upgrading and improvement of decentralized ex situ collections of cucurbits in the North East and fruit tree collections elsewhere. Among these, most work focuses on Passifloraceae, peach palm (Bactris gasipaes), Surinam cherry (Eugenia uniflora), feijoa (Acca sellowiana), guabiju (Myrcianthes pungens), jelly palm (Butia capitata) and Rio Grande cherry (Eugenia involucrata) [60].

Figure 5. Balance between ex situ projects dedicated to underutilized (darker green) versus major crops (light green) in Andean countries.

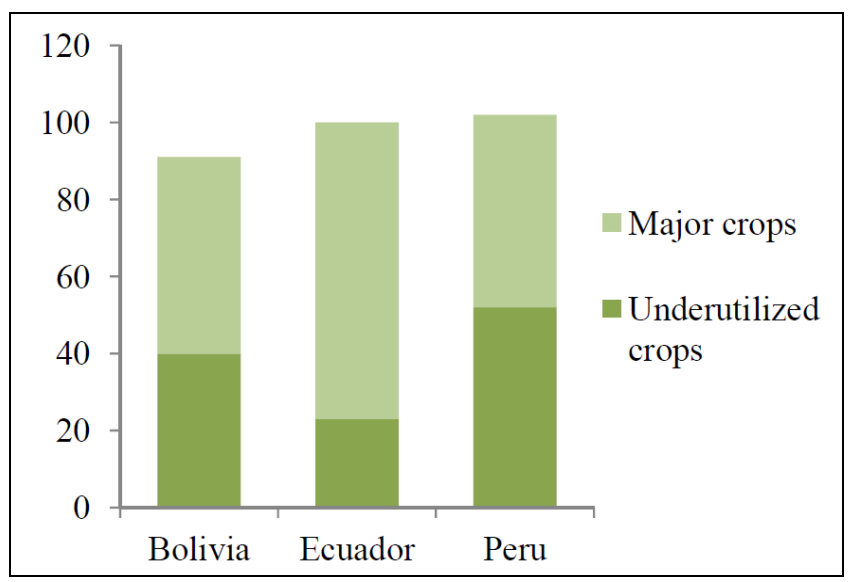

Notwithstanding admirable progress, countries' reports to FAO still highlight a worrying limitation in the funds available, both in amount and regularity. All countries report greater financial shortcomings 
for species whose conservation is not through seed but in vitro or, even more, as field collections, which is the case for most fruit species and is clearly reflected in the numbers presented above.

Within the projects reported under the GPA in situ priority activities, an average $28 \%$ of conservation projects in selected countries are dedicated to underutilized species figuring in our list. Top percentages were reached in Peru (43\%), covering 22 underutilized crops as defined in our survey (Figure 6). Crops in which most effort has been placed are Andean grains (particularly quinoa in Bolivia) and tubers (highest effort being in Peru), followed by specific fruit families (Passifloraceae, Caricaceae and Annonceae).

Figure 6. Balance between in situ projects dedicated to underutilized (darker green) versus major crops (light green) in Andean countries.

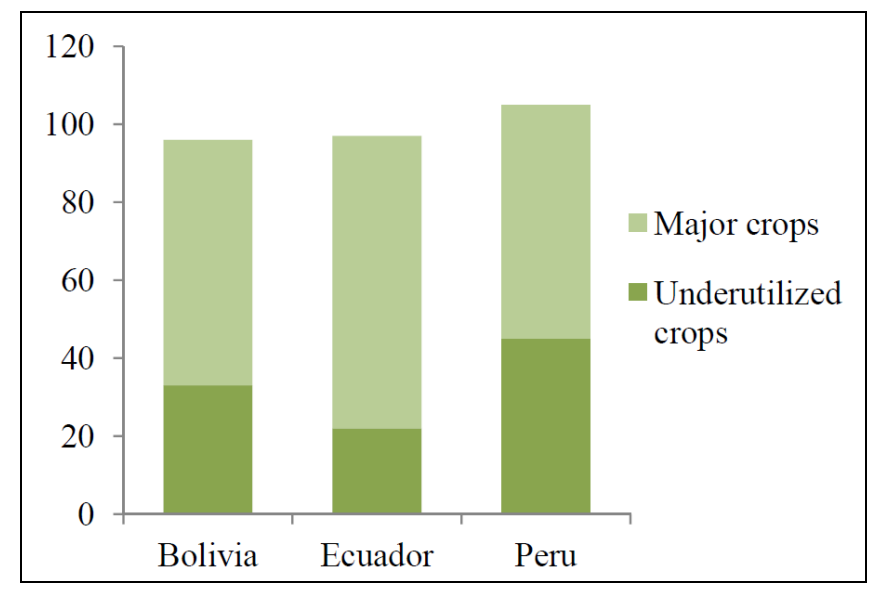

In these countries, many of the projects have focused on registering and documenting on-farm crop diversity and its associated traditional knowledge at local levels. In Peru these efforts have led to the identification of specially managed areas of agricultural biodiversity such as the well-known Potato Park [61]. In Bolivia, ten micro-centers of crop diversity have been identified across six departments and special initiatives such as inventories of on-farm agricultural biodiversity and traditional knowledge, seed fairs and repatriation of native varieties from genebanks have been carried out there [57]. In Ecuador, initiatives ranged from the local establishment of conservation gardens for Andean roots and tubers in farmers' fields to characterization and on-farm conservation projects on fruit species, particularly papayas and cherimoyas [58]. The Brazilian Ministry of Environment, in collaboration with research institutions (such as national research organization Embrapa and the Amazon National Research Institute, INPA) led the identification and the mapping of landraces and wild relatives of some of the main crops grown in Brazil. Seven subprojects involve two of the species here listed as underutilized (cucurbits and peach palm). A number of public institutions often in collaboration with NGOs and the civil society have been active in recovering and documenting local crop landraces, and reintroducing them in cultivation among small scale farmers. However, most initiatives have focused on major staples, namely maize and beans [60]. In Mexico, national surveys of the flora were conducted to establish a baseline of the conservation status for future monitoring: of the 62 plant families prioritized, 19 included food crops, only few of which correspond to those listed here, namely species of the Opuntia genus, squashes, beans and chilli (Capsicum chinense) [62]. 


\section{Discussion and Conclusions}

The first part of the study confirmed the complexity of defining neglect and underutilization and the great variation which exists among NUS species: not all of the common assumptions hold true for different species, each of which may suffer more under some aspects than others. This makes a univocal definition of NUS a challenging endeavor, which, in the words of regional experts, also affects the possibility of well-grounded priority setting exercises for improving the conservation and sustainable use of the genetic resources of minor crops at regional level. A way to address this issue could be to adopt a framework for the analysis of any crop's status based on the number of the typical features of neglect and underuse which affect it, and the degree to which each such features limit its development. We chose the following approach to somehow validate and quantify our crops' status by checking if they met at least three among the following thresholds, which were established on the basis of the results of our analyses:

- be relatively neglected by scientific research (here, we chose the average number of Google Scholar hits across our sample set of species as a threshold, i.e., species with less than 1,954 hits are neglected in this aspect)

- be under-represented in the publicly available dataset of the GBIF (here, less than 126 georeferenced observations in Latin America, the average across our sample set, is the threshold)

- be not represented in FAOSTAT

- have a low number of registered varieties, a proxy of scarce plant breeding and seed commercialization (less than 20 registered commercial varieties, with this threshold corresponding to the average number of varieties registered in national catalogues of commercial plant varieties and in the national lists of plant varieties protected by plant breeders' rights and plant patents for the species from our list)

- be under-represented in globally accessible germplasm collections (by less than 320 accessions, the threshold corresponding to the average accession number of the species considered here in such collections)

The application of the above filtering criteria and thresholds (calculations were performed in R [63]) retained 74 of the crops (i.e., those for which more than three typical features of neglect and underuse held true), while the ten species listed in Table 8 did not qualify as (fully) neglected or underutilized.

The top three crops in Table 8 are globally distributed and consumed, likely explaining why they retain none of the features commonly related to neglect and/or underuse. Other crops have a more intermediate status: cassava (Manihot esculenta), albeit not seriously neglected by research and conservation efforts, is still relatively underused partially because of the limited availability of commercial varieties for larger scale cultivation. The presence of quinoa (Chenopodium quinoa), often referred to as a typical NUS, in Table 8, suggests it is not as seriously overlooked as other Andean native crops, particularly in terms of research, but that it still suffers from limitations in terms of accessibility of germplasm and of conservation-relevant data. On the other hand, the absence of fruit species and most roots and tubers from Table 8 confirms that the majority (often all) of NUS features hold true for the two most numerous categories of NUS reported in the survey. Most of these species appear to be both neglected by research and conservation efforts as well as underused in commercial 
production, because of the limited availability of agricultural statistics and of commercial varieties. The non-staple, non-commodity nature of fruit species, the generally limited long-term storability of their products and the inherent complexities of conserving and breeding species with vegetative propagation are probably the main reasons for their status. For promoting these species, efforts are required all along the conservation-to-use realm. In particular, a focus on on-farm conservation may be particularly appropriate given the difficulties of conserving fruit trees, roots and tubers ex situ; engagement of farmers in collaborative research projects for improving agronomic and processing aspects would provide incentives for the continued on-farm conservation of these species' genetic resources, enhancing their use potential; awareness raising efforts to highlight the role of these crops in diets and health, will be crucial to foster consumer demand and in turn, enhance commercial use.

Table 8. Crops which were not validated as underutilized according to the pilot framework proposed here.

\begin{tabular}{llll}
\hline Crop & Common Name & Origin & \multicolumn{1}{c}{ Aspects in which Underutilized (<3) } \\
\hline Capsicum spp. & Chili peppers & native & None \\
Ipomoea batatas & Sweet potato & native & None \\
$\begin{array}{l}\text { Phaseolus vulgaris } \\
\text { Cajanus cajan }\end{array}$ & Common bean & native & None \\
Fagopyrum esculentum & Pigeon pea & introduced & Lack of widely available distribution data (GBIF) \\
Manihot esculenta & Cassava & introduced & Lack of widely available distribution data (GBIF) \\
Vigna unguiculata & Cowpea & native & Limited commercial varieties available \\
Chenopodium quinoa & Quinoa & native & Lack of widely available distribution data (GBIF) \\
& & & $\begin{array}{l}\text { Low number of accessions in international genebanks } \\
\text { and lack of widely available distribution data (GBIF) }\end{array}$ \\
Cucurbita spp. & Squashes & native & $\begin{array}{l}\text { Not represented in FAOSTAT and no international } \\
\text { descriptors available }\end{array}$ \\
& & & Limited representation in literature and not \\
Phaseolus coccineus & Runner bean & native & represented in FAOSTAT \\
\hline
\end{tabular}

While local, context-dependent expert knowledge and perceptions remain essential to assessing the possibly underexploited potential of any species, the availability of a validation method may provide for a more systematic definition of the extent to which crops present features of neglect and/or underuse and highlight where the major limitations and opportunities for improvement lie (e.g., if in research or conservation efforts, or in options for increased commercial use). This may better support the identification and prioritization of species or categories affected by similar constraints and planning for specific interventions to strengthen different areas along the conservation-use realm. Naturally, different threshold values and a different number of minimum conditions to be fulfilled can be tested, adapting the approach flexibly in consultation with experts' and depending on different contexts and time frames.

International frameworks aimed at conservation and use of plant genetic resources have had mixed, sometimes conflicting effects on the conservation and use of neglected crops. The GPA has probably helped to channel national and international funds to projects which meet its goals, allowing them to gain visibility, but the extent to which it has been the actual driver of these initiatives is not clear, among others because it lacks a financial scheme. While the Convention on Biological Diversity and 
the Treaty on Plant Genetic Resources for Food and Agriculture have contributed to overall international awareness of the importance of agricultural biodiversity, their translation into practical measures for the conservation and sustainable use of minor crops at national levels has been limited. Important areas of influence of the CBD and the Treaty on minor crops are perceived to be those of access and benefit sharing, and experts have highlighted the importance of addressing the widespread lack of harmonized implementation of ABS mechanisms in countries which are Parties to both conventions, particularly when they harbor native, underutilized crops. Such harmonization is crucial for promoting the mobilization of genetic diversity of these species and encouraging research and development while ensuring equitable participation of all relevant actors.

The financial mechanisms of these two international instruments have provided very modest funds to the conservation, characterization and use of genetic resources of NUS to date. The relative dilution of agricultural biodiversity and NUS projects within the GEF's funding on biodiversity is somewhat understandable considering the broad mandate of the CBD (which encompasses all biodiversity) and the quantity of proposals focused on wild biodiversity conservation submitted to the GEF by organizations working in a mega-diverse region such as Latin America. The relatively limited coverage of NUS by the projects supported by the Treaty's benefit sharing fund may be due to a combination of factors, among which the partial reduction in scope in the latest BSF's call, the limited funds yet available through this funding mechanisms, and possibly the lack of NUS-based proposals received from applicants. If the latter hypothesis were the case, it may in turn reflect limited capacity, interest or resources at national level for participating in the competitive tender with NUS-based proposals, or a perception that this framework is not entirely appropriate for conservation and use of minor crops. Results of our survey suggest that the latter hypothesis may be at least partly true; there appears to be a widespread perception that the mechanisms and provisions of the Treaty are tailored exclusively around the Annex 1 list of crops, i.e., mostly major species. While an Annex 1 focus (which is a matter of prioritization rather than exclusivity) is correct for the functioning of the MLS and the Trust's disbursements, we have explained how the benefit sharing fund has only partially restricted, in one of its funding windows, its scope to Annex 1 crops and therefore still promises to be an important opportunity for NUS-centred projects to receive support. It would be important to confirm if this somewhat narrow interpretation of the Treaty is indeed in place, and in that case, address it through capacity building and awareness raising in developing countries. Efforts in this direction should cover other important sections of the Treaty, such as [54] Article 6 on the sustainable use of PGRFA, and [54] Article 9 on farmers' rights, which also constitute very appropriate umbrellas for non-project based initiatives targeting NUS. A certain lack of awareness around the potential for NUS of these provisions may be the result of their rather general nature, which leaves it up to countries to devise relevant national measures. In order for these Treaty provisions to translate into national-level measures favourable to conservation and use of minor species parties may need more guidance on what types of interventions would be relevant. Some advances in this direction have been made in relation to [54] Article 9 on farmers' rights: recommendations to the Treaty's Governing Body on means for recognizing and implementing such rights have included an emphasis on participatory plant breeding $[64,65]$ and other approaches to conservation and use that rely on farmers' participation, such as community seed banks and local seed production [66]. Given the fact that a considerable amount of the genetic resources of minor crops and of the knowledge about their diversity resides in farmers' 
fields, adopting such community-based and participatory approaches may be particularly advantageous for meeting the combined goal of recognizing farmers' rights and halting genetic erosion.

It is important to acknowledge that other drivers are likely to be far more influential in defining countries' priority crops and research and development strategies. Market demand is likely one of the most powerful; increasing customer demand on national and international markets for specialty products from a number of minor crops may already be an important incentive for moving forward national level research and development (and to a certain extent conservation through use), becoming more powerful than any international instrument or funding scheme. Although markets have been quite extensively analyzed for their sometimes controversial effects leading to erosion of diversity and unequal participation $[67,68]$, their potentially positive driving role in the conservation and sustainable use of PGRFA has also been recognized [69-73].

As expressed by the experts in Latin America, the contribution of international frameworks has so far remained mostly at the level of rhetorical discourse; however, these instruments do have a potential to better contribute to improving minor crops' status, by raising worldwide awareness and funds for the conservation and sustainable utilization of their genetic resources. At the same time, they cannot replace national efforts: initiatives at national and local levels are necessary to prioritize, define and implement practical measures that can effectively address the diversity of issues affecting each particular species. Our results allow a better appreciation of the complex nuances which characterize the status of crops commonly bulked under the NUS label; we show how different crops or crop categories are underutilized to very different degrees and in different aspects and suggest practical means to quantify these differences. We believe the application of an analytical approach such as the one presented here provides a basis for informing more targeted, case-specific measures in the field of minor crops' genetic resource management. Finally, in addition to better targeted interventions in the genetic resource conservation and use area, to truly leverage the role of these species, it will be important to link up with national and international initiatives in the fields of sustainable agriculture, food security and sovereignty [74], health [75,76], and adaptation to climate change [77], as minor crops can substantially contribute to the achievement of these objectives.

\section{Acknowledgments}

The authors wish to thank all participants to the survey for taking time to provide the initial data for this article. They also wish to thank Toby Hodgkin and Marleni Ramirez for their insights and intellectual inputs, and Stefano Padulosi for facilitating the authors' participation in relevant meetings and providing contacts of relevant regional experts. Finally, they wish to thank the four anonymous reviewers for their useful comments. The financial support to publish this work open-access comes from the CGIAR Research Programme on Policies, Institutions and Markets. The authors are grateful for this support.

\section{Author Contributions}

Galluzzi, G. designed and undertook data collection and analyses. López Noriega, I. provided substantial contributions to the survey design and the section on international policies, both in terms of analyses and writing. 


\section{Conflicts of Interest}

The authors declare no conflict of interest.

\section{References and Notes}

1. PAR. Biodiversity for Food and Agriculture: Contributing to food security and Sustainability in a Changing World; Outcomes of an Expert Workshop held by FAO and the Platform on Agrobiodiversity Research, Rome, Italy, 14-16 April 2010.

2. FAO. Save and Grow: A Policymakers' Guide to the Sustainable Intensification of Smallholder Crop Production; Food and Agriculture Organization of the United Nations: Rome, Italy, 2011. Available online: http://www.fao.org/docrep/014/i2215e/i2215e.pdf (accessed on 10 July 2013).

3. FAO. Report on the State of the World's Plant Genetic Resources for Food and Agriculture; Food and Agriculture Organization of the United Nations: Rome, Italy, 2010.

4. Prescott, A.R.; Prescott, A.C. How many plants feed the world? Conserv. Biol. 1990, 4, 365-374.

5. Rehm, S.; Espig, G. The Cultivated Plants of the Tropics; Verlag Josef Margraf and CTA: Weikersheim, Germany, 1991.

6. Wilson, E.O. The Diversity of Life; Penguin: London, UK, 1992.

7. Vavilov, N.I. Studies on the origin of cultivated plants. Russ. Bull. Appl. Bot. Plant Breed. 1926, $14,245$.

8. Vavilov, N.I. Origin and Geography of Cultivated Plants; Cambridge University Press: Cambridge, UK, 1992.

9. National Research Council. Lost Crops of the Incas: Little-Known Plants of the Andes with Promise for Worldwide Cultivation; National Academy Press: Washington, DC, USA, 1989.

10. Hazell, P. The Green Revolution. In Oxford Encyclopedia of Economic History; Mokyr, J., Ed.; Oxford University Press: Oxford, UK, 2003.

11. Padulosi, S.; Eyzaquirre, P; Hodgkin, T. Challenges and strategies in promoting conservation and use of neglected and underutilised crop species. In Perspectives on New Crops and New Uses; Janick, J., Ed.; ASHS Press: Alexandria, VA, USA, 1999.

12. Padulosi, S.; Hoeschle-Zeledon, I.; Bordoni, P. Minor crops and underutilised species: Lessons and prospects. In Crop Wild Relative Conservation and Use; Maxted, N., Ford-Lloyd, B.V., Kell, S.P., Iriondo, J.M., Dulloo, M.E., Turok, J., Eds.; CAB International: Wallingford, UK, 2008; pp. 605-624.

13. Thies, E. Promising and Underutilised Species, Crops and Breeds; Deutsche Gesellschaft Für Technische Zusammenarbeit (GTZ): Eschborn, Germany, 2000. Available online: http://www.ilri.cgiar.org/InfoServ/Webpub/fulldocs/AnGenResCD/docs/PDFFORMATFILES/Pr omUnderutilizeSpecCropBreed.pdf (accessed on 15 August 2013).

14. Williams, J.T.; Haq, N. Global Research on Underutilised Crops. An Assessment of Current Activities and Proposals for Enhanced Cooperation. International Centre for Underutilised Crops (ICUC): Southampton, UK, 2002.

15. Padulosi, S.; Hoeschle-Zeledon, I. Underutilised plant species: What are they? Available online: http://www.mtnforum.org/sites/default/files/publication/files/3800.pdf (accessed on 15 August 2013).

16. Google Scholar. Available online: http://scholar.google.com.co/ (accessed on 03 July 2013).

17. Genesys. Available online: http://www.genesys-pgr.org/ (accessed on 03 July 2013). 
18. Ebert, A. Asegurando nuestro futuro: colecciones de germoplasma del CATIE. Securing our future: CATIE's germoplasm collections; Boletín Técnico (CATIE): Turrialba, Costa Rica, 2007. (in Spanish)

19. AVGRIS. AVDRC Vegetable Genetic Resources Information System. Available online: http://203.64.245.173/search.asp (accessed on 03 July 2013).

20. World Information and Early Warning System on Plant Genetic Resources for Food and Agriculture. Available online: http://apps3.fao.org/wiews/wiews.jsp (accessed on 21 June 2013).

21. Country Reports. Available online: http://www.fao.org/agriculture/crops/core-themes/theme/seeds-pgr/ sow/sow2/country-reports/en/ (accessed on 21 June 2013).

22. FAO. Second Report on the State of the World's Plant Genetic Resources for Food and Agriculture; Commission on Genetic Resources for Food and Agriculture, Food and Agriculture Organization of the United Nations: Rome, Italy, 2010.

23. List of International Crop Descriptors. Available online: http://www.bioversityinternational.org/ fileadmin/user_upload/research/research_portfolio/Information_systems_for_crop/List_of_Descri ptor_Titles_2013.pdf (accessed on 29 September 2013).

24. Global Biodiversity Information Facility. Available online: http://data.gbif.org/ (accessed on 20 June 2013).

25. FAOSTAT. Available online: http://faostat.fao.org/ (accessed on 20 June 2013).

26. Plant Variety Database of the Union for Protection of Plant Varieties (UPOV). Available online: https://www3.wipo.int/pluto/user/en/index.jsp (accessed on 29 September 2013).

27. Project database of the Global Environmental Facility. Available online: http://www.thegef.org/ gef/gef_projects_funding (accessed on 1 June 2013).

28. Project database of the Benefit Sharing Fund of the International Treaty on Plant Genetic Resources for Food and Agriculture. Available online: http://www.planttreaty.org/content/ projects-2009-2011 (accessed on 1 June 2013).

29. Project database of the Global Crop Diversity Trust. Available online: http://www.croptrust.org/ content/evaluation (accessed on 17 July 2013).

30. Project database of the Global Plan of Action on Plant Genetic Resources for Food and Agriculture. Available online: http://www.globalplanofaction.org/servlet/CDSServlet?status=ND0xMDcyJjY9 ZW4mMzM9KiYzNz1rb3M (accessed on 17 July 2013).

31. Crops for the Future. Available online: http://www.cropsforthefuture.org/ (accessed on 1 June 2013).

32. Renkow, M.; Byerlee, D. The impacts of CGIAR research: A review of recent evidence. Food Policy 2010, 35, 391-402.

33. Padulosi, S.; Hodgkin, T.; Williams, J.T.; Haq, N. Underutilised Crops: Trends, challenges and opportunities in the 21st century. In Managing Plant Genetic Resources; Engels, J.M.M., Ramanta Rao, V., Brown, A.H.D., Jackson, M.T., Eds.; CABI: Wallingford, UK and IPGRI: Rome, Italy, 2002; pp. 323-338.

34. Van Zonneveld, M; Scheldeman, X.; Escribano, P.; Viruel, M.; van Damme, P.; Garcia, W.; Tapia, C.; Romero, J.; Sigueñas, M.; Hormaza, J.I. Mapping genetic diversity of cherimoya (Annona cherimola Mill.): Application of spatial analysis for conservation and use of plant genetic resources. Plos One 2012, doi: 10.1371/journal.pone.0029845. 
35. Thomas, E.; van Zonneveld, M.; Loo, J.; Hodgkin, T.; Galluzzi, G.; van Etten, J.; Present spatial diversity patterns of Theobroma cacao L. in the neotropics reflect genetic differentiation in Pleistocene refugia followed by human-Influenced dispersal. Plos One 2012, doi:10.1371/journal.pone.0047676.

36. Instituto Brasileiro de Geografia e Estatistica. Available online: http://downloads.ibge.gov.br/ downloads_estatisticas.htm (accessed on 20 October 2013). (In Portuguese)

37. Portal de la Secretaría de Desarrollo Agropecuario del Gobierno del Estado de México. Available online: http://www.edomex.gob.mx/portal/page/portal/sedagro/estadisticas-agropecuarias (accessed on 20 October 2013). (In Spanish)

38. Series históricas de producción agrícola, Ministerio de Agricultura del Perú (in Spanish). Available online: http://frenteweb.minag.gob.pe/sisca/?mod=consulta_cult (accessed on 20 October 2013).

39. Altieri, M.A.; Merrick, L.C. In situ conservation of crop genetic resources through maintenance of traditional farming systems. Econ. Bot. 1987, 41, 86-96.

40. Ceccarelli, S. Evolution, plant breeding and biodiversity. J.Agric. Environ. Int. Dev. 2009, 103, 131-145.

41. Gabriel, J.; Torrez, R.; Thiele, G. Participatory approaches in potato improvement: Experience of PROINPA in Bolivia. In Encouraging Diversity: The Conservation and Development of Plant Genetic Resources; Almekinders, C.J.M., de Boef, W.S., Eds.; Intermediate Technology Publications: London, UK, 2000.

42. Devaux, A.; Thiele, G. Compendio de papa andina, logros y experiencias de la primera fase (1998-2002), (in Spanish); Compendio, International Potato Center (CIP): Lima, Peru, 2002.

43. Gomez, M. Fundación para la Investigación Participativa con Agricultores de Honduras (FIPAH), Yorito, Honduras. Personal communication, 2013.

44. Alonso, S. Asociación de Organizaciones de los Cuchumatanes, ASOCUCH, Huehuetenango, Guatemala. Personal communication, 2013.

45. CBD. Annex of Decision V/5 of the Conference of the Parties to the Convention on Biological Diversity; Convention on Biological Diversity: Montreal, Canada, 2000. Available online: https://www.cbd.int/decision/cop/default.shtml?id=7147 (accessed on 18 February 2014).

46. Fowler, C. Biological diversity in a north-south context. In Green Globe Yearbook; Oxford University Press: Oxford, UK, 1993; pp. 35-44.

47. Sedjo, R. Property rights, genetic resources, and biotechnological change. J Law Econ. 1992, 35, 199-213.

48. Reji, K.J. International regime on access and benefit sharing: Where are we now? Asian Biotechnol. Dev. Rev. 2010, 12, 77-94.

49. Dutfield, G. Intellectual Property Rights, Trade and Biodiversity: The Case of Seeds and Plant Varieties; Oxford University Press: Oxford, UK, 1999.

50. Petit, M.; Fowler, C.; Collins, W.; Correa, C.; Thornström, C.G. Why Governments Can't Make Policy. The Case of Plant Genetic Resources in the International Arena; International Potato Center (CIP): Lima, Peru, 2001.

51. Cabrera Medaglia, J.; Perron-Welch, F.; Rukundo, O. Overview of National and Regional Measures on Access and Benefit Sharing. Challenges and Opportunities in Implementing the Nagoya Protocol, 2nd ed.; Centre for International Sustainable Development Law (CISDL): Montreal, Canada, 2012. 
52. Correa, C.M. Do national access regimes promote the use of genetic resources and benefit sharing? Int. J. Environ. Sus. Dev. 2005, 4, 444-463.

53. Lapeña, I.; Sigüeñas Saavedra, M. Incentives and disincentives for Peru to participate in the multilateral system of the International Treaty on Plant Genetic Resources for Food and Agriculture. In The Multilateral System of Access and Benefit-Sharing. Case Studies on Implementation in Kenya, Morocco, Philippines and Peru; López Noriega, I., Halewood, M., Lapeña, I., Eds.; Bioversity International: Rome, Italy, 2013. Available online: http://www. bioversityinternational.org/nc/publications/publication/issue/the_multilateral_system_of_access_a nd_benefit_sharing.html (accessed on 16 October 2013).

54. FAO. International Treaty on Plant Genetic Resources for Food and Agriculture; Food and Agriculture Organization of the United Nations: Rome, Italy, 2001. Available online: http://www.planttreaty.org/content/texts-treaty-official-versions (accessed on 19 October 2013).

55. GCDT. Towards a Rational Hemispheric Conservation Strategy for Plant Genetic Resources for Food and Agriculture in the Americas. The Global Crop Diversity Trust, Rome, Italy, 2008. Available online: http://www.croptrust.org/documents/regionalstrategies/Americas.pdf (accessed on 12 July 2013).

56. López Noriega, I.; Wambugu, P.; Mejías, A. Assessment of progress to make the multilateral system functional: Incentives and challenges at the country level. In Crop Genetic Resources as a Global Commons. Challenges in International Law and Governance; Halewood, M., López Noriega, I., Louafi, S., Eds; Routledge: London, UK and New York, NY, USA, 2013; pp. 199-225.

57. Representación de la FAO en Bolivia; Oficial de Agricultura del Servicio de Semillas y Recursos Fitogenéticos; Vice ministerio de Medio Ambiente, Biodiversidad y Cambios Climáticos del Ministerio de Medio Ambiente y Aguas; Instituto Nacional de Innovación Agropecuaria y Forestal; y Ministerio de Desarrollo Rural y Tierras. Bolivia. Informe Nacional sobre el Estado de los Recursos Fitogenéticos para la Agricultura y la Alimentación; FAO: Rome, Italy, 2009. Available online: http://www.fao.org/docrep/013/i1500e/Bolivia.pdf (accessed on 20 October 2013). (In Spanish)

58. Tapia, C.; Zambrano, E.; Monteros, A. Ecuador. Informe Nacional sobre el Estado de los Recursos Fitogenéticos para la Agricultura y la Alimentación; INIAP and FAO: Quito, Ecuador and Rome, Italy, 2009. Available online: http://www.fao.org/docrep/013/i1500e/ Ecuador.pdf (accessed on 20 October 2013). (In Spanish)

59. Becerra Gallardo, R.; Sigüeñas Saavedra, M. Perú: Segundo informe sobre el estado de los recursos fitogenéticos para la alimentación y la agricultura; INIA and FAO: Lima, Peru and Rome, Italy, 2009. Available online: http://www.fao.org/docrep/013/i1500e/Peru.pdf (accessed on 20 October 2013). (In Spanish)

60. Da Silva Mariante, A.; Amstalden Sampaio, M.J.; Valadares Inglis, M.C., Eds. State of Brazil's Plant Genetic Resources. Second Report; Embrapa and FAO: Brasilia, DF, Brazil and Rome, Italy, 2009. Available online: http://www.fao.org/docrep/013/i1500e/Brazil.pdf (accessed on 20 October 2013).

61. Ruiz, M. Agrobiodiversity Zones and the Register of Native Crops in Peru: Learning from Ourselves; Sociedad Peruana de Derecho Ambiental and Bioversity International: Lima, Perú and Rome, Italy, 2009.

62. Molina Moreno, J.C.; Córdova Téllez, L., Eds. Recursos Fitogenéticos en México para la Alimentación y la Agricultura. Informe Nacional (in Spanish); SAGARPA, SOMEFI and FAO: 
Mexico City, Mexico and Rome, Italy, 2006. Available online: http://www.fao.org/docrep/013/ i1500e/Mexico.pdf (accessed on 20 October 2013).

63. R Development Core Team. R: A Language and Environment for Statistical Computing, version 3.0.0; R Foundation for Statistical Computing: Vienna, Austria, 2013. Available online: http://www.R-project.org (accessed on 10 May 2013).

64. Chiarolla, C., Jungcurt, S. Outstanding Issues on Access and Benefit Sharing under the Multilateral System of the International Treaty of Plant Genetic Resources for Food and Agriculture; Background study paper, The Bern Declaration and the Norwegian Development Fund: Lausanne, Switzerland and Lisaker, Norway, 2011. Available online: http://www.evb.ch/ cm_data/ITPGR_ABS_Study_1.pdf (accessed on 25 October 2013).

65. Halewood, M.; Deupmann, P.; Sthapit, B.; Vernooy, R.; Ceccarelli, S. Participatory Plant Breeding to Promote Farmers' Rights; Bioversity International: Rome, Italy, 2007. Available online: http://www.bioversityinternational.org/e-library/publications/detail/participatory-plant-breeding-topromote-farmers-rights/ (accessed on 23 October 2013).

66. Andersen, R. Realising Farmers' Rights under the International Treaty on Plant Genetic Resources for Food and Agriculture. Summary of Findings from the Farmers' Rights Project, Phase 1; The Fridtjof Nansen Institute: Lisaker, Norway, 2006. Available online: http://www.fni.no/doc\&pdf/FNI-R1106.pdf (accessed on 23 October 2013).

67. Jacobsen, S.E. The situation for quinoa and its production in Southern Bolivia: From economic success to environmental disaster. J. Agron. Crop Sci. 2011, 197, 390-399.

68. Winkel, T.; Bertero, H.D.; Bommel, P.; Bourliaud, J.; Chevarría Lazo, M.; Cortes, G.; Gasselin, P.; Geerts, S.; Joffre, R.; Léger, F.; et al. The sustainability of quinoa production in Southern Bolivia: From misrepresentations to questionable solutions. J. Agron. Crop Sci. 2012, 198, 314-319.

69. Giuliani, A.; Hintermann, F.; Rojas, W.; Padulosi, S., Eds. Biodiversity of Andean Grains: Balancing Market Potential and Sustainable Livelihoods; Bioversity International: Rome, Italy, 2012. Available online: http://www.bioversityinternational.org/uploads/tx_news/Biodiversity_and_ Andean_grains_balancing_market_potential_and_sustainable_livelihoods_1635.pdf (accessed on 20 October 2013).

70. Kruijssen, F.; Giuliani, A.; Sudha, M. Marketing underutilised crops to sustain agrobiodiversity and improve livelihoods. Acta Hort. 2009, 806, 415-422.

71. Gruere, G.L.; Nagarajan, O.; King, E.D.I. The role of collective action in the marketing of underutilized plant species: Lessons from a case study on minor millets in South India. Food Policy 2009, 34, 39-45.

72. Will, M. Promoting Value Chains of Neglected and Underutilized Species for Pro-Poor Growth and Biodiversity Conservation. Guidelines and Good Practices; Bioversity International and Global Facilitation Unit for Underutilized Species (GFU): Rome, Italy, 2008. Available online: http://www.underutilized-species.org/documents/PUBLICATIONS/promoting_vc.pdf (accessed on 20 October 2013).

73. Hellin, J.; Higman, S. Crop diversity and livelihood security in the Andes. Dev. Pract. 2005, 15, 165-174.

74. Altieri, M.A.; Nicholls, C.I. Scaling up agroecological approaches for food sovereignty in Latin America. Development 2008, 51, 472-480. 
75. Johns, T.E.; Eyzaguirre, P.B. Linking biodiversity, diet and health in policy and practice. P. Nutr. Soc. 2006, 65, 182-189.

76. Toledo, A.; Burlingame, B. Biodiversity and nutrition: A common path toward global food security and sustainable development. J. food compo. Anal. 2007, 19, 477-483.

77. Padulosi, S; Heywood, V.; Hunter, D.; Jarvis, A. Underutilised species and climate change: Current status and outlook. In Crop Adaptation to Climate Change; Yadav, S.S., Redden, R., Hatfield, J.L., Hall, A., Eds.; Wiley-Blackwell: Hoboken, NJ, USA, 2011; pp.507-521.

\section{Appendix}

Annex 1. Regional survey on underutilized crops of the Americas and the influence of international policies on biodiversity and plant genetic resources

\section{Background and Assumptions}

Over the last 20 years, significant political developments have changed the regulatory landscape governing the access to, sharing and use of plant genetic resources, especially with the adoption of the Convention on Biological Diversity (CBD) and the International Treaty on Plant Genetic Resources for Food and Agriculture (ITPGRFA).

However, simplification of agricultural landscapes and practices is causing food production to increasingly rely on a small number of globally distributed crops, to the detriment of a variety of local or regional species. Many of these are threatened by socio-economic and cultural factors and neglected by research and development (hence their definition as "NUS, Neglected and Underutilized Species").

Some representatives of the international scientific community have expressed concern about the potential negative effect that policy frameworks could have on NUS, further undermining the recognized role these species can play in diversification, sustainability and resilience of agro-ecosystems as well as their contribution to income, health and nutrition of the poor.

One concern is related to the effects of the concept of national sovereignty over genetic resources, formalized by the CBD. It is perceived that the flow of germplasm may have suffered restrictions, especially in native crops - many of which are NUS — out of some countries' fear of misappropriation of the genetic resources on their territory by a third party.

Another concern lies in the perception that the ITPGRFA is failing to recognize the importance of NUS, by designing its mechanism of access, benefit sharing and funding around a limited number of crops (listed in the Annex 1 of the Treaty, http://www.planttreaty.org/training/annex1_en.htm) selected based on their global importance and countries' interdependence.

While acknowledging the difficulty of isolating effects of political and legal frameworks from economic, social and cultural issues affecting the conservation and use of NUS, we believe that gathering opinions and experiences from regional experts is extremely important for better understanding the relative influence of the different factors and developing a research agenda that will contribute to better conservation and use of NUS in the region. 


\section{Respondent Information}

Q1

Please indicate your name and position/institute your work for. These data are useful for analyzing responses and necessary for following up and involving you in subsequent steps of the study on NUS.

Q2

Within the PGRFA theme, which are your areas of main expertise/interest? Please tick where relevant.

\begin{tabular}{|l|l|}
\hline ex situ conservation & \\
\hline in situ conservation & \\
\hline breeding & \\
\hline policies & \\
\hline Other (please specify) & \\
\hline
\end{tabular}

\section{NUS and Policies}

Q3

Please list the crops in your collection/context of work/country which can be considered NUS (please provide scientific names).

Note: For general information on the definition of NUS, please consult http://www.underutilised-species. org/spotlight/what_are_underutilised_species.asp.

For the purpose of this survey, we invite you to refer to those crop species with under-exploited potential to contribute to food security, ecosystem and nutritional diversification.

Q4

In what area do you consider the NUS indicated above to have the greatest potential? Please insert the name of the species in the most relevant spaces.

For example, it could be "quinoa" in the box corresponding to "Food Security".

\begin{tabular}{|l|l|}
\hline Climate change mitigation & \\
\hline Climate change adaptation & \\
\hline Breeding & \\
\hline Food security & \\
\hline Dietary Diversity & \\
\hline High value products (potential for niche markets) & \\
\hline Agro-ecosystem diversification & \\
\hline Other & \\
\hline
\end{tabular}

Note: The contribution to mitigation derives from an increased sequestration (mostly perennials) or a decreased emission of carbon dioxide (less chemical inputs required). The contribution to adaptation derives from greater resistance to droughts, floods or other extreme events, or from constituting a food or income generating alternative for farmers faced with increasing climate risks.

Q5

Please indicate (by ticking the box) the effect of each of the following limiting factors on conservation, distribution and use of NUS. 


\begin{tabular}{|c|c|c|c|c|c|}
\hline & No effect & $\begin{array}{c}\text { Limited } \\
\text { effect only in } \\
\text { a few NUS }\end{array}$ & $\begin{array}{c}\text { Limited effect } \\
\text { common to } \\
\text { most NUS } \\
\end{array}$ & $\begin{array}{c}\text { Strong effect } \\
\text { in only a few } \\
\text { NUS }\end{array}$ & $\begin{array}{c}\text { Strong effect } \\
\text { common to } \\
\text { most NUS } \\
\end{array}$ \\
\hline \multicolumn{6}{|l|}{$\begin{array}{l}\text { Low number of accessions conserved in } \\
\text { genebanks }\end{array}$} \\
\hline \multicolumn{6}{|l|}{ Poor regeneration status of ex situ material } \\
\hline \multicolumn{6}{|l|}{ Poor documentation on ex situ material } \\
\hline \multicolumn{6}{|l|}{$\begin{array}{l}\text { Complex regulations for access and } \\
\text { distribution of material }\end{array}$} \\
\hline \multicolumn{6}{|l|}{$\begin{array}{l}\text { Lack of funding for ex situ } \\
\text { conservation/management }\end{array}$} \\
\hline \multicolumn{6}{|l|}{$\begin{array}{l}\text { Lack of funding for in situ } \\
\text { conservation/management }\end{array}$} \\
\hline \multicolumn{6}{|l|}{$\begin{array}{l}\text { Decreasing on farm conservation/loss of } \\
\text { traditional knowledge on use }\end{array}$} \\
\hline Lack of attention by research and development & & & & & \\
\hline
\end{tabular}

Please expand your comments and views on the above or other limiting factors.

Q6

Based on your knowledge of the Convention on Biological Diversity (CBD), please indicate its effects in your working context and-most importantly - if it has influenced NUS and other crops differently over the past 20 years.

Note: Please consider the support granted by the CDB to conservation projects and initiatives through the Global Environmental Facility (GEF), which serves as the CBD's financial mechanism.

\begin{tabular}{|c|c|c|c|c|c|c|c|}
\hline & $\begin{array}{c}\text { Positive, } \\
\text { stronger } \\
\text { in NUS }\end{array}$ & $\begin{array}{c}\text { Positive, } \\
\text { stronger } \\
\text { in other } \\
\text { crops }\end{array}$ & $\begin{array}{c}\text { Negative, } \\
\text { stronger } \\
\text { in NUS }\end{array}$ & $\begin{array}{c}\text { Negative, } \\
\text { stronger } \\
\text { in other } \\
\text { crops } \\
\end{array}$ & $\begin{array}{l}\text { Positive } \\
\text { trend in } \\
\text { all crops }\end{array}$ & $\begin{array}{l}\text { Negative } \\
\text { trend in } \\
\text { all crops }\end{array}$ & $\begin{array}{c}\text { No } \\
\text { significant } \\
\text { effect }\end{array}$ \\
\hline \multicolumn{8}{|l|}{ Germplasm acquisition (ex situ) } \\
\hline \multicolumn{8}{|l|}{$\begin{array}{l}\text { Germplasm characterization and } \\
\text { evaluation (ex situ) }\end{array}$} \\
\hline \multicolumn{8}{|l|}{ Germplasm distribution } \\
\hline \multicolumn{8}{|l|}{ In situ/on farm conservation } \\
\hline \multicolumn{8}{|l|}{ Breeding and crop improvement } \\
\hline \multicolumn{8}{|l|}{$\begin{array}{l}\text { Availability of national funds } \\
\text { (for conservation, use, research) }\end{array}$} \\
\hline $\begin{array}{l}\text { Availability of international funds } \\
\text { (for conservation, use, research) }\end{array}$ & & & & & & & \\
\hline
\end{tabular}

Please explain how this policy framework can have affected or may in the future affect the status of NUS in your working context.

Q7

Based on your knowledge of the International Treaty on Plant Genetic Resources for Food and Agriculture (ITPGRFA), please indicate its effects in your working context and - most importantly-if it has influenced NUS and other crops differently since its entry into force. 
Note: Please keep in mind the support granted by the Treaty to ex situ conservation initiatives/projects through its financial mechanisms, the Global Crop Diversity Trust (GCDT).

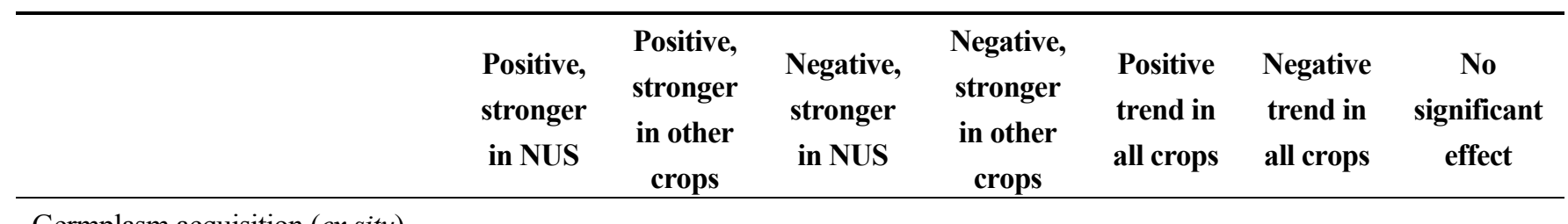

Germplasm acquisition (ex situ)

Germplasm characterization and evaluation (ex situ)

Germplasm distribution

In situ/on farm conservation

Breeding and crop improvement

Availability of national funds (for

conservation, use, research)

Availability of international funds

(for conservation, use, research)

Please explain how this policy framework can have affected or may in the future affect the status of NUS in your working context.

Q8

Do you believe that conservation, management and use of NUS can benefit from the participation of your country in the International Treaty on Plant Genetic Resources for Food and Agriculture? Please explain how. If not, please give reasons. 
Annex 2. List of NUS emerging from the survey

Table A1. List of crops reported as underutilized by plant genetic resource experts in Latin America.

\begin{tabular}{|c|c|c|c|}
\hline Scientific name & Common name in Spanish or local language & English name & Origin \\
\hline Acca sellowiana & Guayabo del país - feijoa & Feijoa & native \\
\hline Amaranthus caudatus & Amaranto - kiwicha - achita & Amaranth & native \\
\hline Amaranthus quitensis & Ataco - sangorache & Amaranth & native \\
\hline Anacardium occidentale & Marañón & Cashew & native \\
\hline Annona cherimola & Chirimoyo & Cherimoya & native \\
\hline Annona muricata & Guanábana & Soursop & native \\
\hline Aristotelia chilensis & Maqui & Chilean Wineberry & native \\
\hline Arracacia xanthorrhiza & Arracacha & White carrot & native \\
\hline Asparagus officinalis & Espárrago & Asparagus & introduced \\
\hline Bactris gasipaes & Pejibaye - chontaduro & Peach palm & native \\
\hline Benincasa hispida & Calabaza china & Winter melon & introduced \\
\hline Berberis spp. & Berberis sp. & Barberry & native \\
\hline Borojoa patinoi & Borojó & Borojó & native \\
\hline Butia capitata & Butiá & Jelly palm & native \\
\hline Cajanus cajan & Guandul & Pigeon pea & introduced \\
\hline Calathea allouia & Dale dale & Guinea arrow root & native \\
\hline Canavalia ensiformis & Canavalia & Jack bean & native \\
\hline Canna edulis & Achira & Achira & native \\
\hline Capsicum spp. & Ajíes & Chili & native \\
\hline Chamaedorea tepejilote & Pacaya & Pacaya palm & native \\
\hline Chenopodium pallidicaule & Cañihua & Cañihua & native \\
\hline Chenopodium quinoa & Quinua & Quinoa & native \\
\hline Chrysobalanus icaco & Icaco & Cocoplum & native \\
\hline Cnidoscolus chayamansa & Chaya & Tree spinach & native \\
\hline Colocasia esculenta & Pituca & Taro & native \\
\hline Cucurbita spp. & Calabazas - zapallos & Pumpkins & native \\
\hline Curcuma longa & Cúrcuma & Turmeric & introduced \\
\hline Cyclanthera pedata & Achocha or cayhua & Stuffing cucumber & native \\
\hline Cynara scolymus & Alcaucil & Artichoke & introduced \\
\hline Cyphomandra betacea & Tomate de árbol & Tree tomato & native \\
\hline Dioscorea trifida & Sacha papa & Indian yam & native \\
\hline Eugenia aggregata & Cereza de Río grande & Rio Grande cherry & native \\
\hline Eugenia stipitata & Arazá & Arazá & native \\
\hline Eugenia uniflora & Grosella - pitanga - cereza de Cayenna & Suriname cherry & native \\
\hline Fagopyrum esculentum & Trigo sarraceno & Buckwheat & introduced \\
\hline Fernaldia pandurata & Loroco & Loroco & native \\
\hline Fragaria chiloensis & Frutilla chilena - fresa chilena o frutilla blanca & Chiloé strawberry & native \\
\hline Frantzia tacaco & Tacaco & Tacaco & native \\
\hline Hexachlamis edulis & Ubajay & Ubajay & native \\
\hline Inga feuillei & Pacay & Pacay or ice-cream bean & native \\
\hline Ipomoea batatas & Batata - papa dulce - camote & Sweet potato & native \\
\hline
\end{tabular}


Table A1. Cont.

\begin{tabular}{|c|c|c|c|}
\hline Scientific name & Common name in Spanish or local language & English name & Origin \\
\hline Lablab purpureus & Zarandaja, frijol trepador & Hyacinth bean & introduced \\
\hline Luffa cylindrica & Estropajo & Sponge gourd & introduced \\
\hline Lupinus mutabilis & Tarwi & South American Lupin & native \\
\hline Mammea americana & Mamey & Mamey & native \\
\hline Manihot esculenta & Yuca & Cassava & native \\
\hline Maranta arundinacea & Jamachipeke & Arrowroot & native \\
\hline Mirabilis expansa & Chago & Pepper weed & native \\
\hline Myrcianthes pungens & Guaviyú & Guaviyú & native \\
\hline Myrciaria dubia & Camu Camu & Camu Camu & native \\
\hline Opuntia ficus indica & Tuna & Prickly pear & native \\
\hline Oxalis tuberosa & Oca & Oca & native \\
\hline Pachyrhizus ahipa & Ashipa - ajipa & Andean yam bean & native \\
\hline Pachyrhizus erosus & Jícama & Yam bean & native \\
\hline Passiflora ligularis & Granadilla & Sweet granadilla & native \\
\hline Passiflora mollissima & Tumbo - curuba & Banana passionfruit & native \\
\hline Paullinia cupana & Guaraná & Guaraná & native \\
\hline Persea schiedeana & Aguacate silvestre & - & native \\
\hline Phaseolus acutifolius & Frijoles "comunes" & - & native \\
\hline Phaseolus coccineus & Ayocote & Runner bean & native \\
\hline Phaseolus dumosus & Frijol cacha & - & native \\
\hline Phaseolus lunatus & Pallar - frijol Lima & Lima bean & native \\
\hline Phaseolus vulgaris & Frijol ñuña & Popping beans & native \\
\hline Physalis peruviana & Aguaymanto - Uchuva o Uvilla & Inca berry & native \\
\hline Plukenetia volubilis & Sacha inchi & Sacha inchi, Sacha peanut & native \\
\hline Portulaca oleracea & Verdolaga & Pigweed & introduced \\
\hline Pouteria obovata & Lúcuma & Lucuma & native \\
\hline Pouteria sapota & Zapote & Sapote & native \\
\hline Psidium guajava & Guayaba & Guava & native \\
\hline Rubus glaucus & Mora de Castilla & Andes berry & native \\
\hline Sechium edule & Chayote & Pear squash, vegetable pear & native \\
\hline Smallanthus sonchifolius & Yacón & Yacón & native \\
\hline Solanum muricatum & Pepino dulce & $\begin{array}{l}\text { Pepino melon or melon } \\
\text { pear }\end{array}$ & native \\
\hline Solanum quitoense & Lulo & Lulo & native \\
\hline Solanum andigenum & Papas nativas & Native potatoes & native \\
\hline Spondias spp. & Spondiaceas & Mombins & native \\
\hline Stenocereus spp. & Pitaya & Pitaya & native \\
\hline Theobroma grandiflorum & Copoazú & Copoazú & native \\
\hline Tropaeolum tuberosum & Mashua - Isaño & Mashua & native \\
\hline Ullucus tuberosus & Olluco - Ulluco - Papalisa & Ulluco & native \\
\hline Vaccinium meridionale & Agraz - mortiño & - & native \\
\hline Vasconcella spp. & Papaya de altura & Highland papaya & native \\
\hline Vigna unguiculata & Caupí & Cowpea & introduced \\
\hline Xanthosoma spp. & Malanga - quequisque - Walusa & Tannia, yautia & native \\
\hline
\end{tabular}


Annex 3. The ex situ conservation status of NUS in selected countries

Table A2. Number of accessions of selected underutilized species, conserved in genebanks of Andean countries. Source: country report to FAO and WIEWS.

\begin{tabular}{|c|c|c|}
\hline Crop & No. Accessions & Holding Institutions \\
\hline Ipomoea batatas & 8 & Vallecito Bolivia \\
\hline Xanthosoma sagittifolium & 11 & INIAF Bolivia \\
\hline Lupinus mutabilis & 12 & INIAF Bolivia \\
\hline Canna edulis & 17 & INIAF Bolivia \\
\hline Pachyrhizus ahipa & 18 & INIAF Bolivia \\
\hline Amaranthus caudatus & 19 & CIBREF-FCAP-UTO Bolivia \\
\hline Pachyrhizus tuberosus & 22 & INIAF Bolivia \\
\hline Annona cherimola & 29 & INIAF Bolivia \\
\hline Manihot esculenta & 38 & Vallecito Bolivia \\
\hline Arracacia xanthorrhiza & 41 & INIAF Bolivia \\
\hline Smallanthus sonchifolius & 43 & INIAF Bolivia \\
\hline Passiflora spp. & 49 & INIAF Bolivia \\
\hline Amaranthus caudatus & 51 & INIAF Bolivia \\
\hline Tropaeolum tuberosum & 79 & INIAF Bolivia \\
\hline Lupinus mutabilis & 105 & INIAF Bolivia \\
\hline Amaranthus caudatus & 134 & INIAF Bolivia \\
\hline Ullucus tuberosus & 197 & INIAF Bolivia \\
\hline Phaseolus & 326 & INIAF Bolivia \\
\hline Solanum sp. & 350 & CIBREF-FCAP-UTO Bolivia \\
\hline Capsicum spp. & 447 & INIAF Bolivia \\
\hline Chenopodium pallidicaule & 448 & CIBREF-FCAP-UTO Bolivia \\
\hline Cucurbita spp. & 450 & INIAF Bolivia \\
\hline Oxalis tuberosa & 487 & INIAF Bolivia \\
\hline Chenopodium pallidicaule & 801 & INIAF Bolivia \\
\hline Chenopodium quinoa & 1,700 & CIBREF-FCAP-UTO Bolivia \\
\hline Solanum spp. * & 1,760 & INIAF Bolivia \\
\hline Chenopodium quinoa & 3,121 & INIAF Bolivia \\
\hline Dioscorea spp. & 1 & DENAREF-INIAP Ecuador \\
\hline Opuntia spp. & 1 & DENAREF-INIAP Ecuador \\
\hline Spondias dulcis & 1 & DENAREF-INIAP Ecuador \\
\hline Myrciaria dubia & 1 & Station Napo Payamino - INIAP Ecuador \\
\hline Annona cherimola & 1 & Station Napo Payamino - INIAP Ecuador \\
\hline Theobroma grandiflorum & 1 & Station Napo Payamino - INIAP Ecuador \\
\hline Annona muricata & 1 & Station Napo Payamino - INIAP Ecuador \\
\hline Eugenia stipitata & 1 & Station Napo Payamino - INIAP Ecuador \\
\hline Spondias purpurea & 1 & Station Napo Payamino - INIAP Ecuador \\
\hline Annona cherimola & 1 & Station Portoviejo - INIAP Ecuador \\
\hline Annona muricata & 1 & Station Portoviejo - INIAP Ecuador \\
\hline Annona cherimola & 2 & DENAREF-INIAP Ecuador \\
\hline Annona muricata & 2 & DENAREF-INIAP Ecuador \\
\hline Vigna unguiculata & 2 & DENAREF-INIAP Ecuador \\
\hline
\end{tabular}


Table A2. Cont.

\begin{tabular}{|c|c|c|}
\hline Crop & No. Accessions & Holding Institutions \\
\hline Chenopodium pallidicaule & 3 & DENAREF-INIAP Ecuador \\
\hline Passiflora spp. & 3 & Station Napo Payamino - INIAP Ecuador \\
\hline Amaranthus hybridus & 5 & DENAREF-INIAP Ecuador \\
\hline Pachyrhizus erosus & 13 & DENAREF-INIAP Ecuador \\
\hline Eugenia stipitata & 15 & Station Portoviejo - INIAP Ecuador \\
\hline Pachyrhizus ahipa & 17 & DENAREF-INIAP Ecuador \\
\hline Vaccinium spp. & 29 & DENAREF-INIAP Ecuador \\
\hline Borojoa patinoi & 30 & Station Napo Payamino - INIAP Ecuador \\
\hline Cyclanthera pedata & 33 & DENAREF-INIAP Ecuador \\
\hline Ipomoea batata & 33 & DENAREF-INIAP Ecuador \\
\hline Cyphomandra betacea & 38 & DENAREF-INIAP Ecuador \\
\hline Pachyrhizus tuberosus & 39 & DENAREF-INIAP Ecuador \\
\hline Vasconcella pentagona & 47 & UNL Ecuador \\
\hline Amaranthus caudatus & 54 & DENAREF-INIAP Ecuador \\
\hline Physalis peruviana & 64 & DENAREF-INIAP Ecuador \\
\hline Rubus spp. & 79 & DENAREF-INIAP Ecuador \\
\hline Carica & 113 & DENAREF-INIAP Ecuador \\
\hline Bactris gasipaes & 145 & Station Napo Payamino - INIAP Ecuador \\
\hline Cucurbita spp. & 147 & DENAREF-INIAP Ecuador \\
\hline Solanum quitoense & 163 & UNL Ecuador \\
\hline Solanum quitoense & 168 & DENAREF-INIAP Ecuador \\
\hline Solanum tuberosum (incl. ssp. andigena) & 237 & DENAREF-INIAP Ecuador \\
\hline Passiflora spp. & 239 & DENAREF-INIAP Ecuador \\
\hline Carica sp. & 336 & UNL Ecuador \\
\hline Capsicum annuum & 355 & UNL Ecuador \\
\hline Capsicum spp. & 370 & DENAREF-INIAP Ecuador \\
\hline Lupinus mutabilis & 396 & DENAREF-INIAP Ecuador \\
\hline Chenopodium quinua & 672 & DENAREF-INIAP Ecuador \\
\hline Annona cherimola & 961 & UNL Ecuador \\
\hline Phaseolus spp. & 3,100 & DENAREF-INIAP Ecuador \\
\hline Dioscorea alata & 1 & INIA SURDIGEB Peru \\
\hline Eugenia uniflora & 1 & INIA SURDIGEB Peru \\
\hline Passiflora edulis & 1 & INIA SURDIGEB Peru \\
\hline Spondias spp. & 1 & INIA SURDIGEB Peru \\
\hline Theobroma grandiflora & 1 & INIA SURDIGEB Peru \\
\hline Carica pubescens & 2 & INIA SURDIGEB Peru \\
\hline Annona muricata & 3 & INIA SURDIGEB Peru \\
\hline Physalis peruviana & 3 & INIA SURDIGEB Peru \\
\hline Pachyrrhyzus ahipa & 4 & INIA SURDIGEB Peru \\
\hline Xanthosoma sagittifolium & 4 & INIA SURDIGEB Peru \\
\hline Colocasia esculenta & 6 & INIA SURDIGEB Peru \\
\hline Calathea allouia & 8 & INIA SURDIGEB Peru \\
\hline Amaranthus hybridus & 12 & INIA SURDIGEB Peru \\
\hline Anacardium occidentale & 12 & INIA SURDIGEB Peru \\
\hline
\end{tabular}


Table A2. Cont.

\begin{tabular}{lcl}
\hline \multicolumn{1}{c}{ Crop } & No. Accessions & \multicolumn{1}{c}{ Holding Institutions } \\
\hline Cucurbita spp. & 14 & INIA SURDIGEB Peru \\
Dioscorea trifida & 15 & INIA SURDIGEB Peru \\
Mirabilis expansa & 19 & INIA SURDIGEB Peru \\
Lepidium meyenii & 21 & INIA SURDIGEB Peru \\
Canna indica & 25 & INIA SURDIGEB Peru \\
Plukenetia volubilis & 42 & INIA SURDIGEB Peru \\
Camu camu & 43 & INIA SURDIGEB Peru \\
Cyclanthera pedata & 46 & INIA SURDIGEB Peru \\
Phaseolus lunatus & 47 & INIA SURDIGEB Peru \\
Lucuma obovata & 95 & INIA SURDIGEB Peru \\
Phaseolus vulgaris (ñuna) & 98 & INIA SURDIGEB Peru \\
Capsicum spp. & 105 & INIA SURDIGEB Peru \\
Bactris gasipaes & 113 & INIA SURDIGEB Peru \\
Vigna unguiculata & 114 & INIA SURDIGEB Peru \\
Smallanthus sonchifolius & 136 & INIA SURDIGEB Peru \\
Passiflora spp. & 158 & INIA SURDIGEB Peru \\
Arracacia xanthorrhiza & 174 & INIA SURDIGEB Peru \\
Opuntia ficus indica & 176 & INIA SURDIGEB Peru \\
Cyphomandra betacaea & 193 & INIA SURDIGEB Peru \\
Capsicum pubescens & 200 & INIA SURDIGEB Peru \\
Chenopodium pallidicaule & 267 & INIA SURDIGEB Peru \\
Tropaeolum tuberosum & 310 & INIA SURDIGEB Peru \\
Annona cherimola & 383 & INIA SURDIGEB Peru \\
Amaranthus caudatus & 486 & INIA SURDIGEB Peru \\
Ullucus tuberosus & 702 & INIA SURDIGEB Peru \\
Manihot esculenta & 740 & INIA SURDIGEB Peru \\
Chenopodium quinoa & 1,936 & INIA SURDIGEB Peru \\
Lupinus mutabilis & 2,103 & INIA SURDIGEB Peru \\
Oxalis tuberosa & 2,217 & INIA SURDIGEB Peru \\
\hline & 2 & \\
\end{tabular}

* = including ssp. andigena, native potatoes.

Table A3. Number of accessions of selected underutilized species, conserved in Brazilian genebanks. Source: country report to FAO and WIEWS.

\begin{tabular}{lcc}
\hline \multicolumn{1}{c}{ Crop } & No. Accessions & Holding Institutions \\
\hline Colocasia & 3 & various \\
Eugenia stipitata & 6 & various \\
Pachyrrhizus sp. & 8 & various \\
Dioscorea spp. & 10 & various \\
Spondias purpurea & 11 & various \\
Spondias spp. & 21 & various \\
Arracacia xanthorrhiza & 22 & various \\
Anacardium occidentale & 35 & various \\
Spondias spp. & 42 & various \\
Rubus spp. & 60 & various \\
\hline
\end{tabular}


Table A3. Cont.

\begin{tabular}{lcc}
\hline \multicolumn{1}{c}{ Crop } & No. Accessions & Holding Institutions \\
\hline Myrciaria dubia & 70 & various \\
Acca sellowiana & 76 & various \\
Annona muricata & 105 & various \\
Spondias tuberosa & 123 & various \\
Eugenia uniflora & 132 & various \\
Spondias mombin & 136 & various \\
Acca sellowiana & 165 & various \\
Acca sellowiana & 193 & various \\
Carica papaya & 210 & various \\
Psidium guayaba & 323 & various \\
Theobroma grandiflora & 529 & various \\
Anacardium occidentale & 643 & various \\
Passiflora spp. & 1,292 & various \\
Vigna unguiculata & 1,787 & various \\
Phaseolus lunatus & 2,673 & various \\
Capsicum spp. & 3,137 & various \\
Cucurbita spp. & 5,675 & various \\
\hline
\end{tabular}

Table A4. Number of accessions of selected underutilized species, conserved in genebanks of Mexico. Source: WIEWS.

\begin{tabular}{lcl}
\hline \multicolumn{1}{c}{ Crop (genus) } & No. Accessions & Holding Institutions \\
\hline Amaranthus spp. & 700 & University of Chapingo \\
Anacardium occidentale & 14 & University of Chapingo \\
Annona cherimola & 2 & INIFAP \\
Annona chirimola & 12 & University of Chapingo \\
Annona muricata & 8 & University of Chapingo \\
Annona squamosa & 1 & INIFAP \\
Bactris gasipaes & 8 & INIFAP \\
Bactris spp. & 1 & University of Chapingo \\
Capsicum annuum & 248 & University of Chapingo \\
Capsicum annuum & 1,211 & INIFAP \\
Capsicum chinense & 25 & University of Chapingo \\
Capsicum chinense & 100 & INIFAP \\
Capsicum spp. & 3,350 & INIFAP \\
Carica papaya & 1 & INIFAP \\
Carica spp. & 60 & INIFAP \\
Chrysobalanus icaco & 1 & University of Chapingo \\
Cnidoscolus chayamansa & 23 & University of Chapingo \\
Colocasia esculenta & 8 & University of Chapingo \\
Cucurbita spp. & 1,580 & INIFAP \\
Dioscorea alata & 6 & University of Chapingo \\
Dioscorea bulbifera & 8 & University of Chapingo \\
Eugenia spp. & 5 & University of Chapingo \\
Feijoa sellowiana & 2 & INIFAP \\
\hline
\end{tabular}


Table A4. Cont.

\begin{tabular}{lcl}
\hline \multicolumn{1}{c}{ Crop (genus) } & No. Accessions & Holding Institutions \\
\hline Hylocereus undatus & 9 & University of Chapingo \\
Ipomea batatas & 15 & University of Chapingo \\
Ipomoea batatas & 178 & INIFAP \\
Lagenaria siceraria & 6 & INIFAP \\
Luffa cylindrica & 2 & INIFAP \\
Mammea americana & 3 & University of Chapingo \\
Manihot esculenta & 30 & University of Chapingo \\
Manihot spp. & 200 & INIFAP \\
Manilkara zapota & 9 & University of Chapingo \\
Maranta arundinacaea & 2 & University of Chapingo \\
Opuntia spp. & 133 & INIFAP \\
Pachyrhizus erosus & 49 & INIFAP \\
Passiflora edulis & 4 & University of Chapingo \\
Passiflora edulis & 2 & INIFAP \\
Persea americana & 14 & University of Chapingo \\
Persea americana & 58 & INIFAP \\
Phaseolus acutifolius & 88 & University of Chapingo \\
Phaseolus acutifolius & 40 & INIFAP \\
Phaseolus coccineus & 209 & University of Chapingo \\
Phaseolus dumosus & 104 & University of Chapingo \\
Phaseolus lunatus & 93 & University of Chapingo \\
Pouteria sapota & 5 & University of Chapingo \\
Psidium guajaba & 8 & University of Chapingo \\
Psidium guajava & 4 & INIFAP \\
Psidium spp. & 4 & University of Chapingo \\
Rubus occidentalis & 63 & INIFAP \\
Sechium edule & University of Chapingo \\
Spondias mombim & University of Chapingo \\
Spondias purpurea & & University of Chapingo \\
\hline & & \\
& 37 &
\end{tabular}

(C) 2014 by the authors; licensee MDPI, Basel, Switzerland. This article is an open access article distributed under the terms and conditions of the Creative Commons Attribution license (http://creativecommons.org/licenses/by/3.0/). 